\title{
Pollen-based temperature and precipitation inferences for the montane forest of Mt. Kilimanjaro during the last Glacial and the Holocene
}

\author{
L. Schüler ${ }^{1,2}$, A. Hemp ${ }^{1}$, and H. Behling ${ }^{2}$ \\ ${ }^{1}$ Department of Plant Systematics, University of Bayreuth, Bayreuth, Germany \\ ${ }^{2}$ Department of Palynology and Climate Dynamics, University of Göttingen, \\ Göttingen, Germany
}

Received: 11 December 2013 - Accepted: 29 December 2013 - Published: 15 January 2014

Correspondence to: L. Schüler (lisa.schueler@uni-bayreuth.de)

Published by Copernicus Publications on behalf of the European Geosciences Union.

\section{Pollen-based temperature and precipitation inferences \\ L. Schüler et al.}

\section{Title Page}

\section{Full Screen / Esc}

Printer-friendly Version

Interactive Discussion 


\section{Abstract}

The relationship between modern pollen-rain taxa and measured climate variables was explored along the elevational gradient of the southern slope of Mt. Kilimanjaro, Tanzania. Pollen assemblages in 28 pollen traps positioned on 14 montane forest vegetation 5 plots were identified and their relationship with climate variables was examined using multivariate statistical methods. Canonical correspondence analysis revealed that the mean annual temperature, mean annual precipitation and minimum temperature each account for significant fractions of the variation in pollen taxa. A training set of 107 modern pollen taxa was used to derive temperature and precipitation transfer functions based on pollen subsets using weighted-averaging-partial-least-squares (WA-PLS) techniques. The transfer functions were then applied to a fossil pollen record from the montane forest of Mt. Kilimanjaro and the climate parameter estimates for the Late Glacial and the Holocene on Mt. Kilimanjaro were inferred. Our results present the first quantitatively reconstructed temperature and precipitation estimates for Mt Kilimanjaro and give highly interesting insights into the past $45000 \mathrm{yr}$ of climate dynamics in tropical East Africa. The climate reconstructions are consistent with the interpretation of pollen data in terms of vegetation and climate history of afro-montane forest in East Africa. Minimum temperatures above the frostline as well as increased precipitation turn out to be crucial for the development and expansion of montane forest during the Holocene. In contrast, consistently low minimum temperatures as well as about $25 \%$ drier climate conditions prevailed during the pre LGM, which kept the montane vegetation composition in a stable state.

In prospective studies, the quantitative climate reconstruction will be improved by additional modern pollen rain data, especially from lower elevations with submontane dry forests and colline savanna vegetation in order to extend the reference climate gradient.

\section{CPD}

$10,195-234,2014$

\section{Pollen-based temperature and precipitation inferences}

L. Schüler et al.

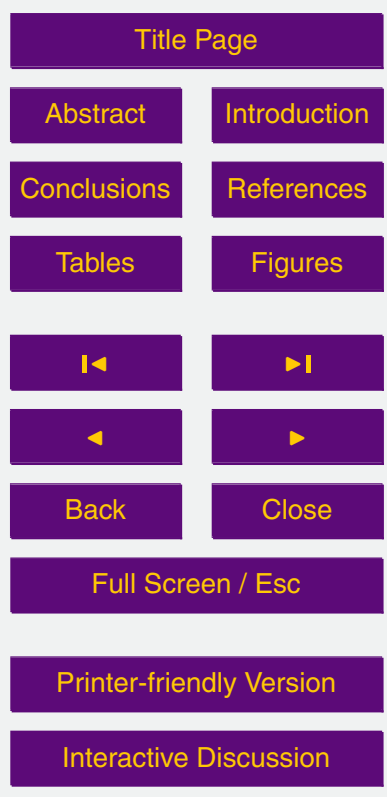




\section{Introduction}

Many environmental issues, like global warming or altered precipitation patterns, have increased the interest in fossil species assemblages as indicator of the palaeoenvironment. In palaeoecology the direct measurement of environmental variables is 5 impossible; consequently there is the need to resort to indirect methods. Fossil taxa assemblages can provide a record of the palaeoenvironment since each biological species requires particular environmental conditions for regeneration, establishment and growth. Today, this principle idea is primarily used in biomonitoring (Spellerberg, 1991). Nevertheless, it is also possible to infer the past environmental conditions at 10 a site from the species composition that occurred there. Fossil taxa records are valuable for obtaining a historical perspective of current environmental problems such as acid rain (Battarbee, 1984) and global warming (Fritz et al., 1991; Walker et al., 1991).

The earliest attempt to quantitatively reconstruct past climate using pollen data was the use of indicator taxa in pollen records (Conolly, 1961; Zagwijn, 1960, 1994; Faegri and Iversen, 1989). Several numerical procedures for quantitatively reconstructing past environments from fossil pollen assemblages have been developed in the past decades; these include transfer functions (Imbrie and Kipp, 1971; Bartlein et al., 1984), pollen response surface (Bartlein et al., 1986; Prentice et al., 1991), modern analogue technique (Nakagawa et al., 2002; Overpeck et al., 1985; Guiot, 1990), and weighted averaging (Birks, 1995, 1998; Birks et al., 1990; ter Braak and Juggins, 1993; Li et al., 2007; Jongman et al., 1995). Such techniques have been widely applied to many palaeo-records worldwide, such as Europe (Huntley and Prentice, 1988; Guiot et al., 1989; Birks, 1995; Seppä et al., 2004), Asia (Xu et al., 2009; Li et al., 2007; Nakagawa et al., 2002), America (Webb III and Bryson, 1972; Markgraf et al., 2002) (1972), who were the first to develop transfer function for the pollen assemblage in lake sediments, developed their transfer function based only on 8 pollen types since they excluded many pollen types for a variety of reasons (local origin, function of human

10, 195-234, 2014

\section{Pollen-based temperature and precipitation inferences}

L. Schüler et al.

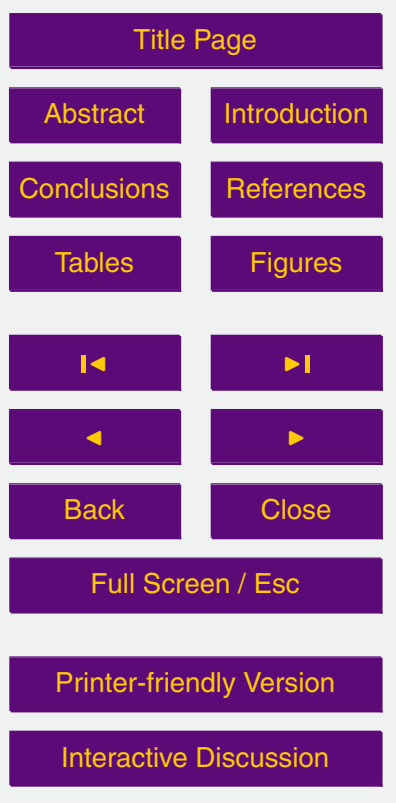

Interactive Discussion 
disturbance, pollen under- or overrepresentation of taxa). Bonnefille et al. (1992), who made quantitative estimates of glacial temperatures from palynological data in Burundi also eliminated taxa with values less than $2 \%$ and taxa that occurred in less than $10 \%$ of the total number of samples.

5 As mentioned above, it requires a representative training set consisting of data on species assemblages and associated environmental measurements. Relationships between species and environmental variables are generally nonlinear. Because of Shelford's law of tolerance (Odum, 1971) and niche-space partitioning (Whittaker et al., 1973), species abundance or probability of occurrence is often a unimodal function of 10 the environmental variables.

Palaeoecological transfer functions share the several characteristics (Sachs et al., 1977). They produce calibrated quantitative estimates of environmental parameters of a past environment. They make use explicit algebraic methods to formulate these estimates. The applied algorithms rely on multivariate techniques to analyse multicom15 ponent fossil data. The transfer functions are calibrated from a training data set, an adequate sample of modern distributional data. The calibrated function is then applied to older samples to estimate environmental parameters for past times.

In palaeo-ecology, the weighted averaging (WA) method gained popularity because it combines niche-space partitioning with empirical predictive power (Birks et al., 1990; 20 Fritz et al., 1991; ter Braak and Juggins, 1993). Ter Braak and Juggins (1993) could show that the addition of a partial least square regression (PLS) to the weighted averaging (WA) method could even further improve the predictive power. They demonstrated that the application of weighted averaging partial least square regression (WAPLS) could reduce the prediction error by up to $70 \%$. The main advancement of the

WA-PLS procedure is that it is unimodal-based (since it is based on the niche-space partitioning concept and ecological optima of species) unlike the PLS which is linearbased (ter Braak and Juggins, 1993; Birks, 1993). Further strength of this multivariate calibration-function approach is its relative robustness to spatial autocorrelation and its applicability in extrapolation of parameters (Birks et al., 2010; Bartlein et al., 2011).

\section{CPD}

10, 195-234, 2014

\section{Pollen-based temperature and precipitation inferences}

L. Schüler et al.

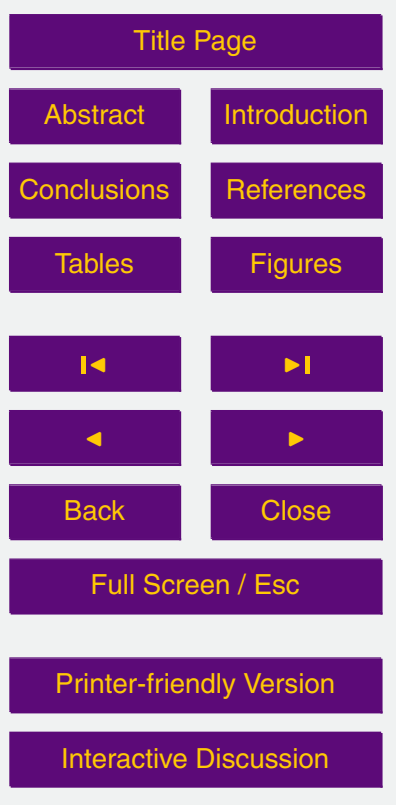


These recent advances in quantitative environmental reconstruction procedures now allow palaeoecologicts to explore many critical ecological questions, answers to which require the unique long-term temporal perspective provided by palaeoecology. What are the rates of change in ecological processes? Which processes result in given eco5 logical thresholds being crossed, or resilience? Did novel systems, non- analogue systems, occur in the past and which combination of factors did lead to such systems (Willis et al., 2010a)? Answers to these questions (Froyd and Willis, 2008; Willis et al., 2010b; Macdonald et al., 2008) highlight the contributions that palaeoecological reconstruction can make in understanding ecological and evolutionary processes responsi10 ble for biodiversity patterns (Birks et al., 2010).

The central assumption in plant ecology is that climate has the dominant control on the distribution of the major vegetation types of the world. The climate space required to describe taxa distributions requires at least two dimensions related to temperature and water availability because of the existence of bioclimatic limits on the distribution of taxa 15 (Woodward and Williams, 1987; Harrison et al., 2010). At the global scale responses to extreme minimum temperatures and to the hydrological budget predict the distribution limits of the major vegetation (Woodward and Williams, 1987). Further, frost stress plays a decisive role in plant distribution since it serves as a very selective filter and operates over very long time scales (Larcher and Bauer, 1981; Sakai and Larcher,

\section{low temperature extremes (Körner, 2003).}

Fossil pollen records provide evidence of changing plant compositions through time (Pickett et al., 2004; Marchant et al., 2009; Prentice et al., 2000). Pollen can often be identified to genus and family level, but only rarely to species level. Higher taxa levels tend to have distributions as coherent as lower taxa or species in climate space (Wake et al., 2009; Huntley et al., 1989). Bioclimatic limits determine the fundamental niche of taxa, but niches of taxa, especially at higher level, commonly overlap. They also vary in abundance; either with maximum values near physiological optima, or displaced by competition. Therefore more-or-less continuous variation in taxa abundance

\section{CPD}

10, 195-234, 2014

\section{Pollen-based temperature and precipitation inferences}

L. Schüler et al.

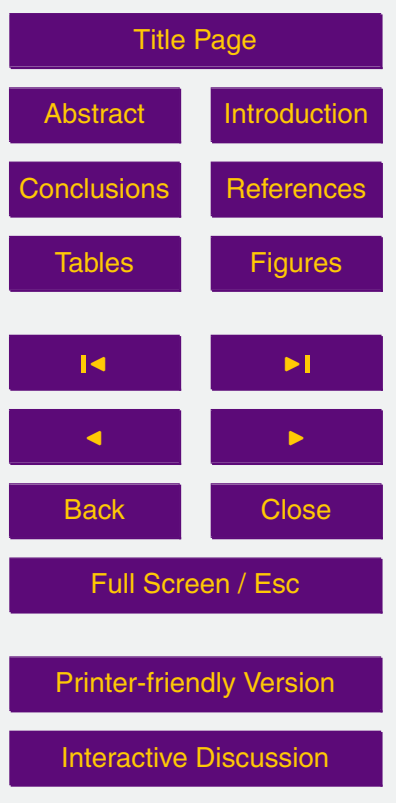

Interactive Discussion 
along environmental gradients in space are found, and we can establish relationships between taxa composition and climate parameter space (Jackson and Williams, 2004).

This present study aims at the development of an ecologically plausible and significant transfer functions through the calibration of the relationships between modern 5 pollen assemblages, vegetation belts and several ecologically determinant climate parameters such as mean annual temperature (MAT), mean annual precipitation (MAP) and minimum temperature (Tmin) in the Kilimanjaro area. The transfer functions are then applied to the fossil WeruWeru 26 pollen record from 2600 ma.s.I. on the SE slope of Mt. Kilimanjaro to reconstruct the past vegetation and climate dynamics of equatorial East Africa of the past about 50 kyrBP.

\section{Study site}

Mt. Kilimanjaro is a relict of an ancient volcano, which was formed as part of the East African Rift Zone. It is located at the border to Kenya $300 \mathrm{~km}$ south of the equator in Tanzania and about $300 \mathrm{~km}$ west of the Indian Ocean (Fig. 1a). It rises from savanna 15

\subsection{Vegetation}

Mt. Kilimanjaro has several different bioclimatic zones (Fig. 1b and c): the dry and hot colline savanna zone surrounds the mountain base between 700 and 1100 ma.s.l. Most of this area is used for crop production (maize, beans and sunflowers) or as meadows. Remnants of the former savanna woodlands (Acacia, Terminalia, Grewia, and Combretum) are encountered mainly around Lake Chala in the eastern foothills and on the northwestern side of the mountain. The submontane and lower montane forest belts between 1000 and $1800 \mathrm{~m}$ have been converted to coffee-banana fields, a special type of agroforestry called "Chagga home gardens". Remnants of the former

\section{CPD}

10, 195-234, 2014

\section{Pollen-based temperature and precipitation inferences}

L. Schüler et al.

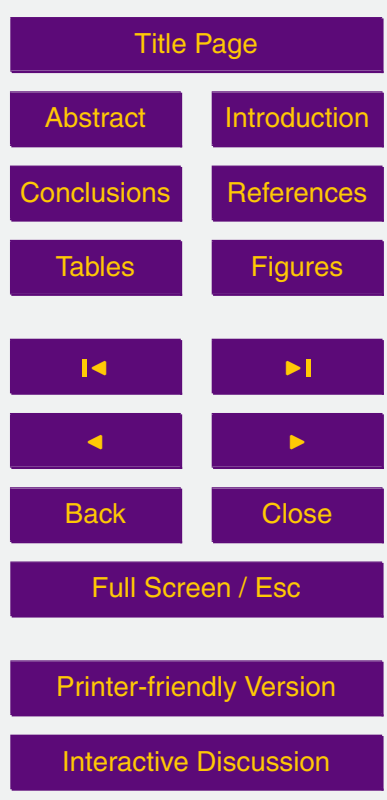


to deep valleys and gorges. Montane tropical rain and cloud forests on Mt Kilimanjaro cover an area of about $1000 \mathrm{~km}^{2}$.

The WeruWeru 26 (WW26) study site $\left(03^{\circ} 07^{\prime} 18.1^{\prime \prime} \mathrm{S}, 37^{\circ} 16^{\prime} 17.7^{\prime \prime} \mathrm{E}\right)$ is located at 2650 ma.s.I. on the southern slope of Mt. Kilimanjaro in the WeruWeru river area

5 (Fig. $1 \mathrm{~b}$ and c). In the lower montane zone (1800-2000 ma.s.l.) of the WeruWeru area Macaranga kilimandscharica, Agauria salicifolia and Ocotea umsabarensis are the dominant tree species. This part of Kilimanjaro's forests is influenced by human activities such as fodder and wood collection and grazing by cattle. WW26 is located in the mid montane zone, which starts in the WeruWeru area at $2000 \mathrm{~m}$ and end at $2700 \mathrm{~m}$ 10 elevation. In this zone, humidity reaches its maximum, indicated by the wealth of epiphytes and ferns, in particular filmy ferns and tree ferns. Evergreen forest species such as Ocotea umsabarensis, Xymalos monospora, Ilex mitis and Schefflera volkensii build up the tree layer. More detailed description of these vegetation types are published by Hemp (2001, 2006a, b).

\subsection{Climate}

Due to its equatorial location, the Mt. Kilimanjaro area is characterized by a typical tropical daytime climate. The precipitation pattern follows the position of the intertropical convergence zone (ITCZ) and is strongly influenced by the activity of the Indian monsoon system. According to Köppen and Troll/Pfaffen (in Müller, 1989), Mt. Kili20 manjaro can be assigned to a seasonal dry tropical climate with two pronounced wet seasons: a short one in November/December and a longer one from March to May. Annual precipitation is modified by elevation and exposure to prevailing winds blowing inland from the Indian Ocean and varies on the wet southern slope from $500 \mathrm{~mm}$ at the mountain foothills to about $3000 \mathrm{~mm}$ at 2200 ma.s.l. (Fig. 1b). At higher altitudes of $2700 \mathrm{~m}, 3000 \mathrm{~m}$ and 4000 ma.s.l., rainfall amounts to roughly 70,50 and $20 \%$, respectively of this annual maximum (Hemp, 2001, 2006b). The northern slopes receive less annual rainfall than the southern slopes. The mean annual temperature decreases from $23.4^{\circ} \mathrm{C}$ at the foothills in Moshi, 813 ma.s.l. (Walter et al., 1975) linearly to $-7.1^{\circ} \mathrm{C}$

\section{CPD}

10, 195-234, 2014

\section{Pollen-based temperature and precipitation inferences}

L. Schüler et al.

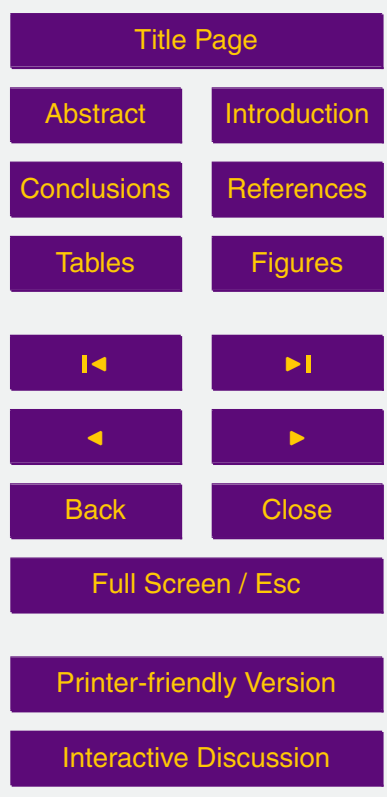

Interactive Discussion 
at the summit (Kibo, 5895 ma.s.I.) (Thompson et al., 2002). Temperature lapse rates vary from 0.51 to $0.56{ }^{\circ} \mathrm{C}$ per $100 \mathrm{~m}$ elevation (Hemp, 2006b). Frost occurs from $2700 \mathrm{~m}$ upwards (Hemp, 2006a).

\section{Material and method}

\section{$5 \quad 3.1$ The pollen record}

In total 76 samples were taken every $2 \mathrm{~cm}$ from a $165 \mathrm{~cm}$ long WeruWeru 26 (WW26) sediment core. The core was obtained from a soil pit by hammering five $50 \mathrm{~cm}$ long zinc metal cases consecutively into the pit wall. Due to the high content of un-decomposed material it was only possible to extract sediment from $15 \mathrm{~cm}$ below the soil surface downwards. The material was wrapped into plastic foil and kept under cool and dark conditions until transported back to the University of Göttingen. For pollen analysis a sample volume of $0.5 \mathrm{~cm}^{3}$ was prepared in the lab applying the standard method (Faegri and Iversen, 1989). The extracted pollen samples were mounted in glycerine jelly for pollen identification and counting.

15 The chronology is based on 13 AMS dated samples (see Supplement); 11 samples were dated at the Physical Institute of the University Erlangen-Nuremberg/Germany and two samples by Beta Analytic in Miami, Florida/USA. According to the results, samples from 17 to $52 \mathrm{~cm}$ core depth can be assigned to the Holocene. Samples between 66 and $165 \mathrm{~cm}$ core depth belong to the Late Pleistocene. There was no pollen in the sediment below $123 \mathrm{~cm}$ depth.

\subsection{Modern pollen-rain data}

The pollen and climate data sets used for the training data set included the 14 plots of the WeruWeru transect on the southern slope of Kilimanjaro. The modern pollen-rain was captured in pollen traps installed on 14 montane forest plots every $100 \mathrm{~m}$ elevation between 1900 and 3200 ma.s.l. On each plot the rainfall was recorded using dipping 202

\section{CPD}

$10,195-234,2014$

\section{Pollen-based temperature and precipitation inferences}

L. Schüler et al.

Title Page

\section{Full Screen / Esc}

Printer-friendly Version

Interactive Discussion 
bucket rain gauges and in parallel funnel-gauges. Data loggers were used for temperature. The instruments were accurate within $\pm 1 \mathrm{~mm}$ and $\pm 0.1^{\circ} \mathrm{C}$, respectively. Mean annual precipitation (MAP), mean annual temperature (MAT) and absolute minimum temperature (Tmin) were calculated based on data recorded from the years 2005 to 5 2013. For the climate parameter reconstruction the developed transfer functions were applied to the data set of the WW26 sediment core containing in total 76 samples.

Chemical preparation of past and modern pollen samples followed standard methods (Faegri and Iversen, 1989). The extracted pollen samples were mounted in glycerine jelly for pollen identification and counting. At least 300 pollen grains were counted for 10 each sample. Pollen determination was carried out using light microscopy with $400 \times$ and $1000 \times$ magnification. Pollen identification referred to collections at Göttingen University, the African Pollen Database (Lézine, 2001) and Assemien et al. (1974). The pollen sum was used for the calculation of the pollen taxa abundance (in \%). The fern spore abundance (\%) was computed based on the pollen sum but it is not included in 15 it.

\subsection{Numerical analyses and subset selection}

An ordination derives quantitative information on the relationship among species, environmental variables and sites (Legendre and Legendre, 2012) In quantitative environmental reconstructions the first step is to examine whether linear or unimodal methods 20 are appropriate for the available training set in relation to the environmental variables of interest (Birks, 1995; Lotter et al., 1997). For this purpose the modern pollen-rain data set was analysed by Detrended Correspondence Analysis (DCA) to estimate the lengths of environmental gradient inherit in the data. To visualize the response of each pollen taxa to the climate variables, the taxa percentage at each site/elevation was plot25 ted again the climate parameters measured at these sites. A local regression function (alpha: 0.45) was fitted to visualize the response trend. Further, in order to estimate the explanatory power of MAP, MAT and Tmin, three Canonical Correspondence Analyses (CCA) were performed using each climate parameter as sole constraining variable.

\section{CPD}

10, 195-234, 2014

\section{Pollen-based temperature and precipitation inferences}

L. Schüler et al.



Interactive Discussion 
This ordination method is preferably applied to data of species abundance and relative frequency that have a large number of zero values (Legendre and Legendre, 2012). DCAs and CCAs were carried out using CANOCO 4.54 (ter Braak and Šmilauer, 1997; 2002) and summarized in Table 2.

$5 \quad$ Forward selection was used to select a subset of the explanatory pollen taxa for each climate variable individually so that each pollen taxa present in the subset specifically contributes to the explanatory power of the subset. Pollen taxa with a contribution of $\geq$ $20 \%$, representing the percentage contribution of the particular taxa to the explanatory power of the whole subset of taxa, were selected (Table 3).

\subsection{WAPLS climate reconstruction and assessment of model performance}

For the climate variables MAP, MAT and Tmin, pollen-based inference models were developed using weighted-averaging-partial-least-squares (WAPLS) models (ter Braak and Juggins, 1993). The WA-PLS procedure and the reconstruction was computed using the program R and the "rioja" package (Juggins, 2012). In applications like the present one, large test sets are not available; instead the prediction errors are simulated by bootstrap cross-validation (number of boot cycles: 1000). The goal of bootstrapping is to assign measures of accuracy to sample estimates.

Since it is not easily possible to quantitatively estimate to what degree pollen taxa abundance represents rather a function of local origin and/or pollen under- or overrepresentation, three WA-PLS calibration functions were developed, each on nontransformed and transformed species subsets (as selected by forward selection for each climate variable) for a comparison. Finally, the models were used to reconstruct MAP, MAT and Tmin based on the WW26 pollen data set. The root-mean-square error of prediction (RMSEP) is a frequently used measure of the differences between values predicted by a model and the values observed. Further, checking the predictive worth of an environmental model includes a goodness of fit metric $\left(R^{2}\right)$ to quantify the degree of matching to recorded data, thereby giving a measure of model performance. Standard goodness-of-fit statistics as $R^{2}$ are an appropriate measure for model evaluation

CPD

10, 195-234, 2014

\section{Pollen-based temperature and precipitation inferences}

L. Schüler et al.

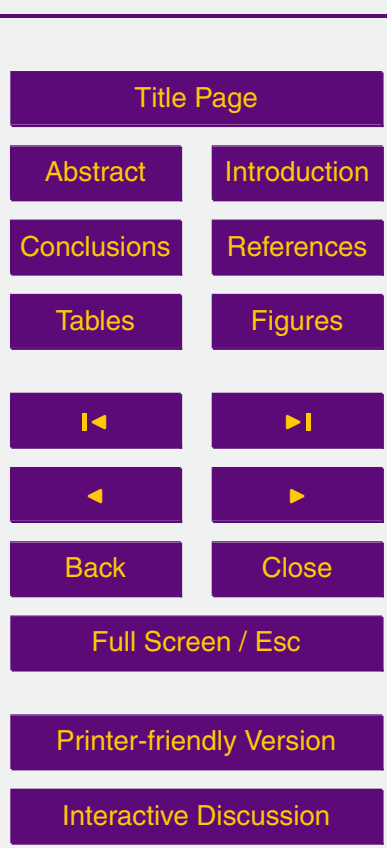


(Guiot and Vernal, 2007). A randomized $t$ test was used to test the significance level of the WAPLS components. Subsequently, the significant WAPLS components were used for the transfer-functions. Error bars indicate the standard error of bootstrap climate parameter estimates.

5 A principle component analysis (PCA) was performed on the fossil pollen data set of WW26 to derive main trends in vegetation change over time. The data set was square root transformed prior to the ordination to reduce the effects of over-represented taxa in the pollen record.

\section{Results} \\ 4.1 MAP, MAT and Tmin along the WeruWeru transect}

Figure 2 shows the trend of MAP, MAT and Tmin along the elevational gradient between 1900 and 3200 ma.s.l. of the southern slope of Mt. Kilimanjaro. Starting off with $2750 \mathrm{~mm}$ (at 1900 ma.s.I.) the MAP peaks at $2300 \mathrm{~m}$ elevation with about $3450 \mathrm{~mm}$ rainfall. It then gradually decreases with increasing elevation to $1600 \mathrm{~mm}$ at 3200 ma.s.I. MAT (Fig. 2b) shows a linear decrease in temperature uphill. While the MAT reaches $14.2^{\circ} \mathrm{C}$ at 1900 ma.s.l., in drops to $7.06^{\circ} \mathrm{C}$ at 3200 ma.s.l.

Tmin of the recorded time period shows a linearly decreasing trend with increasing elevation (Fig. 2c). At 1900 ma.s.l., the lowest temperature recorded was $6.01{ }^{\circ} \mathrm{C}$. A Tmin of $-1.2^{\circ} \mathrm{C}$ was recorded at 3200 ma.s.l. The frost line is crossed at about 2840 ma.s.l. as suggested by interpolation of the local regression function. However, temperatures below zero were also recorded at 2700 ma.s.l.

\subsection{Pollen taxa response to MAP, MAT and Tmin gradients}

In Fig. 3 the response functions of several representative pollen taxa (Araliaceae, Olea, Macaranga and Podocarpus) to MAP, MAT and Tmin are depicted.

\section{CPD}

10, 195-234, 2014

\section{Pollen-based temperature and precipitation inferences}

L. Schüler et al.

\section{Title Page}

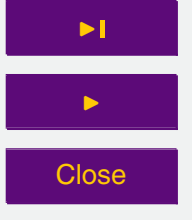

Full Screen / Esc

Printer-friendly Version

Interactive Discussion 
Araliaceae pollen grains are most abundant at site with $2090 \mathrm{~mm}$ and at $2220 \mathrm{~mm}$ MAP ( $23 \%$ of the recorded pollen sum and $18 \%$ respectively) (Fig. 3a). Lowest abundance values are recorded at sites with annual rainfall of 1610 to $1830 \mathrm{~mm}$ and with MAP $>2900 \mathrm{~mm}$. Despite the strong variation of abundance, Araliaceae pollen 5 shows a unimodal response to MAP with an optimum abundance at sites with 1800 to $2400 \mathrm{~mm}$ of rainfall. Olea pollen has the highest abundance at $1930 \mathrm{~mm}$ MAP. At lower and higher precipitation, the abundance decreases gradually. Macaranga pollen grains show an abundance of about 5 to $15 \%$ at every site (MAP range: 1600 to $3450 \mathrm{~mm}$ ) except for three: at locations with 3670, 2920 and $2750 \mathrm{~mm}$ MAP this pollen taxon is 10 very abundant (70 to $75 \%$ ). Podocarpus pollen grains show a unimodal response to MAP with highest abundance of $43 \%$ at $2210 \mathrm{~mm}$ of rainfall. The abundance decreases gradually with higher and lower MAP.

The MAT plot (Fig. 3b) shows that Araliaceae pollen grains are abundantly recorded (18 to $24 \%$ ) at sites ranging from 8.5 to $11.0^{\circ} \mathrm{C}$ MAT. At sites with higher or lower MAT (0.3 to $1.4 \%)$ ( (0.3 to $1.4 \%$ ) between 7 and $10.5^{\circ} \mathrm{C}$. Then, with increasing MAT (>11 $\left.\mathrm{C}\right)$, Olea decreases and is not recorded at sites with MAT $>12.6^{\circ} \mathrm{C}$. Macaranga pollen grains show an abundance of about 5 to $15 \%$ at every sites with MAT $<12^{\circ} \mathrm{C}$. Between 12 and $14.3^{\circ} \mathrm{C}$ this pollen taxon is very abundant (70 to $\left.75 \%\right)$. Podocarpus pollen grains are not very common at sites with MAT $<9^{\circ} \mathrm{C}(<9 \%)$. They are most abundant between 9 and $11^{\circ} \mathrm{C}$ and then the record of Podocarpus pollen decreases with increasing MAT.

The response function of the pollen taxa to Tmin is very much alike the one observed from MAT.

\subsection{Multivariate analyses of the modern pollen-rain and subset selection}

25 The Detrended Correspondence Analysis (DCA) of the untransformed modern pollenrain data revealed a length of environmental gradient of 2.49 inherit in the data. This result and the predominantly unimodal response of single pollen taxa suggested to

\section{CPD}

10, 195-234, 2014

\section{Pollen-based temperature and precipitation inferences}

L. Schüler et al.

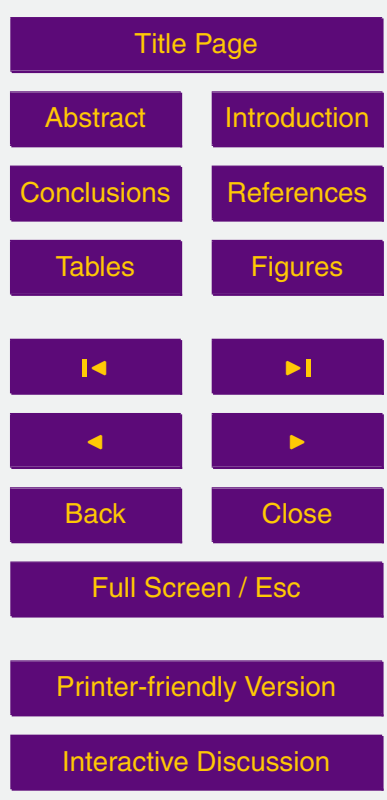


continue with a Canonical Correspondence Analysis (CCA, a unimodal based constrained ordination).

The CCA triplots (Fig. 4a and b) represent simultaneously the ordination of samples (sites labelled with elevation in ma.s.I.), pollen taxa (30\% best fit) and their relationship 5 to climate variables. In the ordination diagrams, the climate variables (MAP, MAT, Tmin) are represented by vectors, the point of direction indicates increasing values of the respective parameter.

The proximity of pollen taxa and sites to any climate parameter can be interpreted as a relative measure for the correlation between those data point. Sites that a closer 10 positioned to climate variable vector respectively, experience higher temperature or precipitation. Taxa that show a positive correlation with either of the climate parameters are most abundant at sites with high values of this parameter.

Hagenia and Erica pollen grains are negatively correlated with all three climate parameters whereas Macaranga shows a positive correlation. Ilex is more strongly corre15 lated with MAP than with MAT, the opposite is the case for Podocarpus pollen grains, which are slightly more correlated with MAT. Taxa that are positioned close to the centre of the ordination diagram do either not show a clear linear relationship with any climate variable, show a unimodal response and/or do not significantly contribute to the variance of the whole data set (hence, the dispersion of taxa within the ordination 20 space).

The summary of the CCA (Table 1) shows that the first two CCA axes with MAP as single constraining variable accounted for $33.46 \%$ of the cumulative variance in the pollen data. For the MAT the first two CCA axes account for $34.52 \%$, for Tmin this is $34.92 \%$. Pseudo-canonical correlation between pollen taxa and the climate variable is 0.943 for MAP, 0.9616 for MAT and 0.9665 for Tmin. The Monte Carlo permutation test results reveal high significance levels for all three climate parameters $(p=0.002)$.

The forward selection revealed 24 pollen taxa with an explanatory contribution $\geq$ $20 \%$ for MAP, 25 taxa for MAT and 15 taxa for Tmin (Table 2).

\section{CPD}

$10,195-234,2014$

\section{Pollen-based temperature and precipitation inferences}

L. Schüler et al.

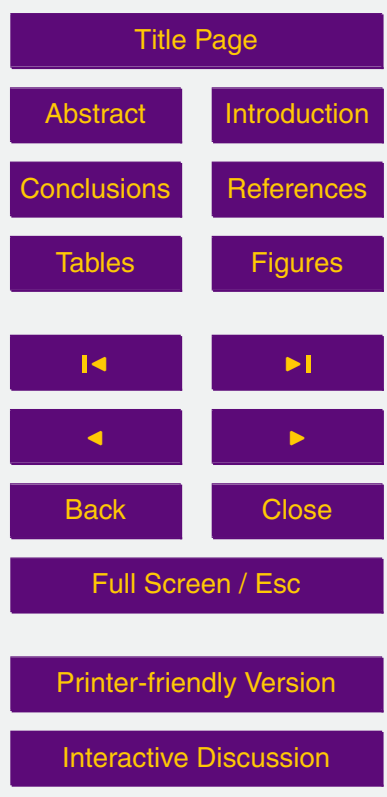




\subsection{Model performance and climate reconstruction of the WW26 pollen record using Weighted-Averaging Least Square Regression (WA-PLS)}

The model performance is summarized by several measures (Table 3 ). The performance of the WA-PLS is expressed by the Root Mean Square Error (RMSEP) of the

5 climate parameter models, based on square-root transformed training subsets. RMSEPs are not standardized but values are expressed in terms of the original variables. The randomized $t$ test results reveal that for MAP, MAT and Tmin only the first WAPLS component $(p<0.001)$ is significant. Hence, these components were used for the transfer-functions. $R^{2}$ refers to the "fraction of variance explained" by the model; the

$R^{2}$ values for MAP, MAT and Tmin reveal a close relationship between the bootstrap cross validated reconstructed and modern climate variables. The error bars indicate the standard error of bootstrap estimated climate parameters of the correspondent WA-PLS component.

Due to sediment loss (hiatus), the palaeosoil sequence between 56 and $66 \mathrm{~cm}$ the 15 Last Glacial Maximum (LGM) is missing. According to the AMS chronology the sequence above the hiatus ( $<56 \mathrm{~cm}$ depth) is made up of mid to late Holocene sediment (ca. 6 to $0 \mathrm{kyrBP}$ ) and the sediment below the hiatus (>66 cm depth) belongs to the mid Last Glacial (ca. 46 to 36 kyrBP).

Earlier than $44 \mathrm{kyrBP}$ our model reconstructs a MAP is between 1530 and $1620 \mathrm{~mm}$. 20 It then reaches a temporary high around $42 \mathrm{kyrBP}$ (around $90 \mathrm{~cm}$ depth, above $1680 \mathrm{~mm}$ ) and then drops back to $1550 \mathrm{~mm}$ soon after (at $85 \mathrm{~cm}$ depth). The remaining time prior to $36 \mathrm{kyrBP}$ MAP fluctuates between 1670 and $1550 \mathrm{~mm}$. In the mid Holocene, just before $6 \mathrm{kyrBP}$, our model reconstructs similar MAP values as for the late Last Glacial (ca. $1650 \mathrm{~mm}$ ). Between 6.1 and $2.6 \mathrm{kyrBP}$ MAP increases rapidly $1.9 \mathrm{kyrBP}$ ( $29 \mathrm{~cm}$ depth). $2030 \mathrm{~mm}$ are reconstructed for the modern pollen rain sample at the study site at 2600 ma.s.l., which very close to the observed precipitation from

\section{CPD}

$10,195-234,2014$

Pollen-based temperature and precipitation inferences

L. Schüler et al.

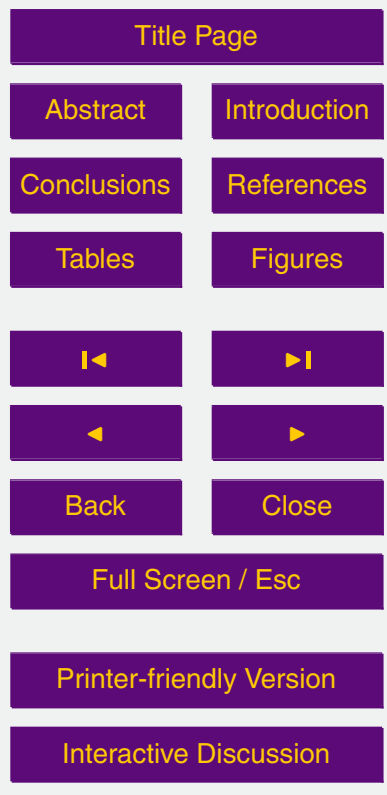

Interactive Discussion 
the site $(2077 \mathrm{~mm})$. The lowest MAP of $1530 \mathrm{~mm}$ is reconstructed for about $45 \mathrm{kyrBP}$ (at $117 \mathrm{~cm}$ depth).

The reconstructed MAT ranges between 7.9 and $8.2^{\circ} \mathrm{C}$ in the lowest part of the record between 95 and $123 \mathrm{~cm}$ depth. It shows an increase to $8.6^{\circ} \mathrm{C}$ around $42 \mathrm{kyrBP}$ $5\left(90 \mathrm{~cm}\right.$ depth). It then drops back to 8.1 to $8.4^{\circ} \mathrm{C}$ until $36 \mathrm{kyrBP}$. The lowest MAT $\left(7.9^{\circ} \mathrm{C}\right)$ is recorded at about $45 \mathrm{kyrBP}\left(113 \mathrm{~cm}\right.$ depth). Temperature around $8.7^{\circ} \mathrm{C}$ are recorded for the mid Holocene. After that, MAT increases rapidly to $8.9^{\circ} \mathrm{C}$ at about $3 \mathrm{kyrBP}(45 \mathrm{~cm})$. Throughout the late Holocene, the temperatures fluctuate between 8.3 and $9.2^{\circ} \mathrm{C}$. The MAT reconstructed for the study sites is $9.6^{\circ} \mathrm{C}$, which is close to 10 today's temperature from the site of $10.1^{\circ} \mathrm{C}$.

The reconstructed Tmin values vary between -1.1 and $-0.4^{\circ} \mathrm{C}$ throughout the preLGM. At no point Tmin exceeds the frostline. In the mid and late Holocene fluctuates strongly between $-1.5^{\circ} \mathrm{C}$ and $+0.5^{\circ} \mathrm{C}$ The lowest $\mathrm{Tmin}$ is recorded in the late Holocene at $2.6 \mathrm{kyrBP}\left(-1.2^{\circ} \mathrm{C}\right)$ and at about $1 \mathrm{ka}\left(-1.5^{\circ} \mathrm{C}\right)$. In the mid and late 15 Holocene the Tmin values frequently exceed the frostline. The Tmin reconstructed for the study site today is $1.1^{\circ} \mathrm{C}$ which is very close to the Tmin of $1.3^{\circ} \mathrm{C}$ observed at 2600 ma.s.l. today.

The PCA based on the WeruWeru pollen record revealed a first principle component (PC 1) reflecting $46.6 \%$ of the variation inherent in pollen record and a second principle component reflecting $25.4 \%$. PC 1 is plotted next to the quantitative climate reconstruction (Fig. 5) to facilitate the detection and interpretation of past forest community and climate patterns. While during the pre-LGM the pollen taxa composition of the site seems to have been rather stable, the Holocene is characterized by major taxa composition changes and fast turnover rates indicated by a rapid change in standard

\section{CPD}

10, 195-234, 2014

\section{Pollen-based temperature and precipitation inferences}

L. Schüler et al.

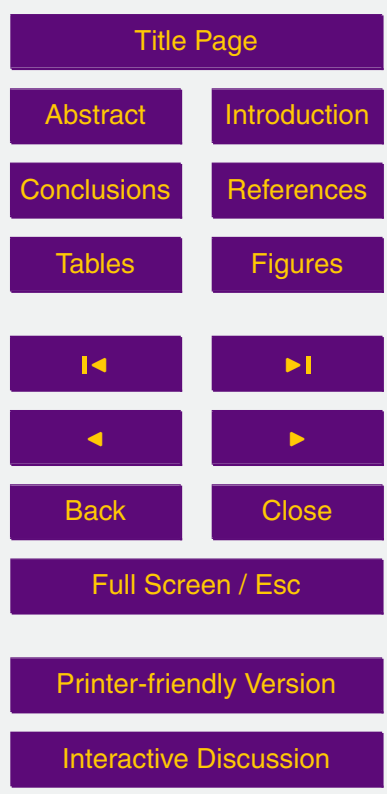




\section{Interpretation and discussion}

The results of the climate record along the WeruWeru transect on the southern slope of Mt. Kilimanjaro between 1900 and 3200 m elevation have shown that the MAP and MAT follow the typical climate gradient observed from mountains located in dry tropical 5 region (Lauer, 1976). While MAT and Tmin show a linear trend along the elevational gradient, the MAP shows a normal distribution with a maximum in mid-altitudes at Kilimanjaro (Hemp, 2006a). Since the investigated elevational gradient starts at an elevation of 1900 ma.s.I., this unimodal trend is not very strong reflected in our results.

\subsection{Pollen taxa responses to climate}

10 The response of the pollen taxa to the climate variables differs between taxa. Despite the fact that the majority of pollen taxa seems to follow a normal distribution along the gradient of climate variables, there are pollen taxa that show a rather directional trend such as Macaranga vs. MAT and Tmin. However, it is known that species abundance is usually a unimodal function of the environmental variable (Odum, 1971; Whittaker

15 et al., 1973). Despite the relative abundance of taxa within the pollen record, the ecological unimodal response to climate parameters can still be observed. In the case of Macaranga and partly Olea, the full elevational abundance gradient, hence ecological optimum curve, was not covered by our modern pollen-rain study. The results of the modern pollen-rain suggest that the abundance of Macaranga as well as Olea ex-

tents to lower elevations below 1900 ma.s.I. accompanied by higher temperatures and lower precipitations (Hemp, personel observation, 2006). Despite potential differences in pollen dispersal patterns between species (as suggested in Schüler, 2013), this unimodal distribution would also hold true for the pollen record. Hence, it can be assumed that directional trends in the taxa abundance along the elevation gradient recorded in this study are rather caused by the incomplete inventory of the climate gradient. This is supported by the fact that the precipitation gradient is not fully captured as can be seen from the recorded MAP (Fig. 2) and when compared to Hemp (2006a). The evaluation

\section{CPD}

10, 195-234, 2014

\section{Pollen-based temperature and precipitation inferences}

L. Schüler et al.

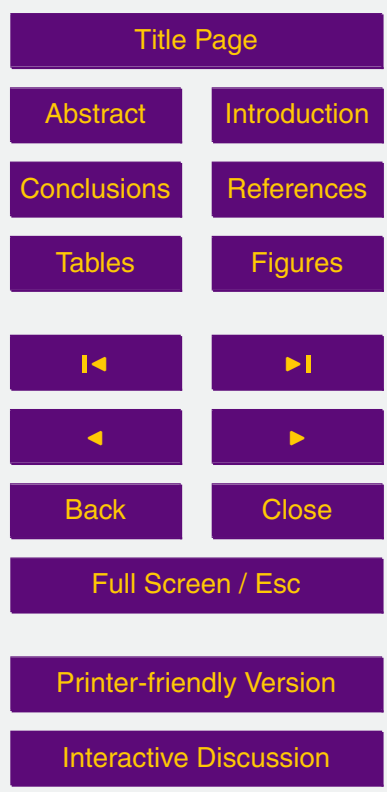


of unpublished data of A. Hemp (600 forest relevées from Kilimanjaro) reveals that all these taxa have a unimodal distribution regarding abundance and biomass along the climatic gradient. Studies on pollen representivity have shown that despite pollen production and dispersal patterns the underlying vegetation composition can still be 5 identified (Schüler, 2013).

Taxa such as Podocarpus and Araliaceae seem to have a rather narrow MAT optimum area whereas Olea and Macaranga are rather tolerant and display a broader temperature optimum. This unimodal response of taxa was further supported by the long environmental gradient revealed by the DCA. The CCA revealed that all the cli10 mate variables are important environmental factors influencing the distribution of the pollen taxa. In all ordinations, the explained variance in the pollen data set is high. The correlation between pollen taxa and the climate variables indicates a strong relationship between species and environment, which is supported by the permutation test results. Based on these outcomes, the quantitative inference models for these variables from 15 the pollen assemblages were developed.

\subsection{Model performance}

The assessment of the pollen training subset selection and the WA-PLS model performance shows that the type of data transformation used plays an important role for the reconstruction. Skewed data and data with many rare or absent taxa are often trans20 formed by taking the square-root (Legendre and Legendre, 2012). Since in our study not only the most abundant pollen taxa (e.g. Ericaceae and Macaranga) show a good correlation with MAP, MAT and Tmin but also taxa that have a low occurrence (e.g. Olea), square-root transformations amplify the weight of these taxa. The normalizing effect of the square-root transformation allows the selection of rare taxa into the subset and relativizes the effect of dominant taxa on the transfer function. Our results show that this is very important to consider when climate parameters are to be reconstructed from pollen taxa compositions instead of single taxa only. Data transformation facilitates rare taxa or the presents and absents of taxa, which can still act as discriminant

\section{CPD}

$10,195-234,2014$

\section{Pollen-based temperature and precipitation inferences}

L. Schüler et al.

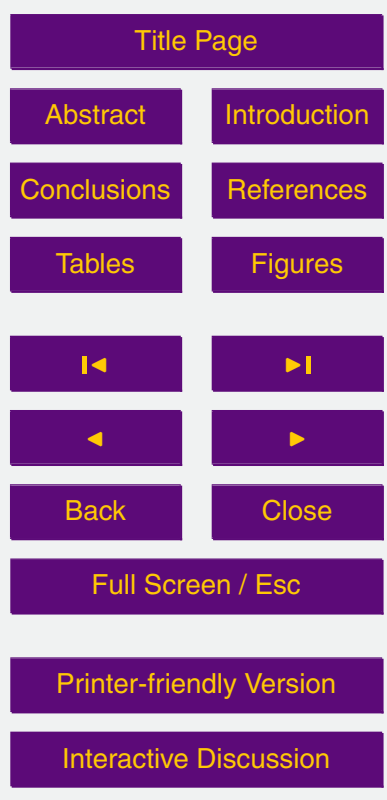

Interactive Discussion 
taxa in the plant ecological context, to act as delimiters or determinants in the climate parameter reconstruction. Hence, the information inherent in rare taxa must not be neglected. Instead, these taxa should receive special attention and need to be reinforced prior to model application. This need is further supported by findings from the 5 montane vegetation of Mt. Kilimanjaro, which demonstrate, that several pollen taxa are over or underrepresented due to differences in plant pollen productivity and possibly wind-caused pollen drift (Schüler, 2013).

\subsection{Pre-LGM climate reconstruction}

The WA-PLS reconstructed climate parameters based on the WeruWeru pollen record 10 give a very nice estimation of the climatic conditions in the Kilimanjaro area in the pre-LGM and the Holocene. Due to the hiatus in the pollen record, the climate reconstruction is not possible for the LGM.

During late pre-LGM (ca. 44 to $36 \mathrm{kyrBP}$ ) MAP is reconstructed to be between 1540 and $1680 \mathrm{~mm}$. This equals a maximum reduction in MAP by $480 \mathrm{~mm}$, which is $24 \%$ than 15 today. Before this period ( $>43 \mathrm{kyrBP}$ ), our model suggests a MAP between 1530 and 1620 (20 and $25 \%$ respectively, less than today). This suggests that the early pre-LGM was slightly drier than the late pre-LGM. During the early pre-LGM, the reconstructed MAT of 7.9 to $8.2^{\circ} \mathrm{C}$ means that it was on average 1.4 to $1.7^{\circ} \mathrm{C}$ cooler than today. After this period until $36 \mathrm{kyrBP}$, our model suggests marginally warmer conditions with 20 temperature of 8.1 to $8.6^{\circ} \mathrm{C}$. Such cool and humid conditions during the period directly preceding the LGM is also proposed by the pollen and d13C record from Mt. Kenya (Olago et al., 1999).

Reconstructed minimum temperatures (Tmin) persistently remain between -0.4 and $-1.1^{\circ} \mathrm{C}$ throughout the pre-LGM.

25 The climate fluctuations are lowest in the early pre-LGM (> $44 \mathrm{kyrBP}$ ) and largest during the Holocene. Humid but stable climate conditions during the early pre-LGM were also observed at Maundi Crater (2780 ma.s.I.) on Mt. Kilimanjaro (Schüler et al., 2012). The relatively warm climatic conditions similar to today are supported by

\section{CPD}

10, 195-234, 2014

\section{Pollen-based temperature and precipitation inferences}

L. Schüler et al.

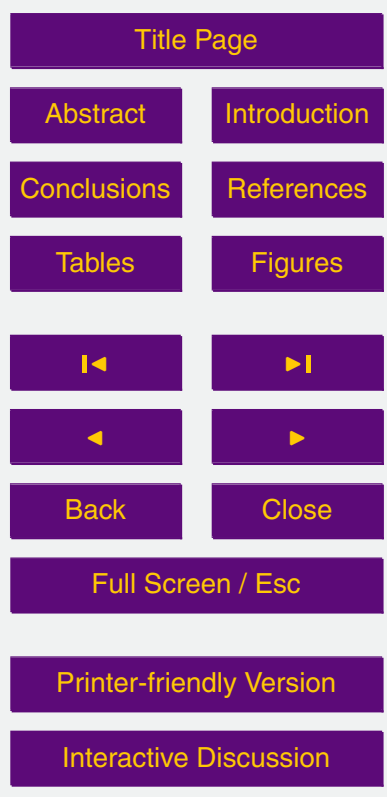

Interactive Discussion 
vegetation reconstructions from the Rukiga highlands in southwest Uganda (Taylor, 1990). In addition, contemporaneous records from Sacred Lake, Mt. Kenya (Coetzee, 1967; Olago, 2001) and Kamiranzovu Swamp (Hamilton, 1982) are in accordance with these results. The increase in shrubs and trees indicate a shift of vegetation zones to 5 higher elevations suggest humid and comparatively warm climate conditions at Maundi Crater (Schüler et al., 2012). Based on Mt. Kilimanjaro temperature lapse rates varying from 0.51 to $0.56{ }^{\circ} \mathrm{C}$ per $100 \mathrm{~m}$ rise (Hemp, 2006b) the reconstructed temperatures at our study site at $2600 \mathrm{~m}$ of 7.9 to $8.2^{\circ} \mathrm{C}$ translate into a vegetation shift of about $300 \mathrm{~m}$ during the late pre-LGM. This is more that Mumbi et al. (2008) recontructed, 10 who observe an altitudinal shift of montane forest from 1700 to 1800 ma.s.l. to 1800 1900 ma.s.I. in the Eastern Arc Mountains of Tanzania. However, this difference could be caused by the shadowing effect of the surrounding mountains in the Eastern Arc, which leads to less extreme climate conditions within in the mountains range compared to freestanding mountains as the Kilimanjaro. Hence, our MAT reconstruction 15 reflects the decreasing temperature trend approaching the LGM. Lake Chala temperature reconstruction based on distributions of branched GDGTs infer LGM temperatures $7-10^{\circ} \mathrm{C}$ lower than today (Sinninghe Damsté et al., 2012) which suggests that a rapid temperature decrease in the Kilimanjaro area occurred after 36 ka. Interesting is, that despite the MAT being slightly higher in the late pre-LGM compared to the early preLGM, the lowest Tmin is reconstructed for the late pre-LGM. This suggests that in spite of the relatively moderate temperatures on average, the frequency and severity of low temperature events increased towards the LGM.

The pollen-based temperature and precipitation reconstruction from Kashiru Swamp at 2104 ma.s.I. in the Burundi Highlands, estimate the LGM climate being by $3-4{ }^{\circ} \mathrm{C}$ cooler and drier (ca. $30 \%$ less rainfall) than today (Bonnefille and Chalié, 2000; Bonnefille et al., 1992). Such LGM temperatures would have caused a descent of vegetation zone on Mt. Kilimanjaro by another 300-400 m after the late pre-LGM. Recent vegetation reconstruction on Mt. Killimanjaro suggest a vegetation shift of about $1000 \mathrm{~m}$ for the LGM (Schüler et al., 2012; Zech, 2006), which corresponds well with

\section{CPD}

10, 195-234, 2014

\section{Pollen-based temperature and precipitation inferences}

L. Schüler et al.
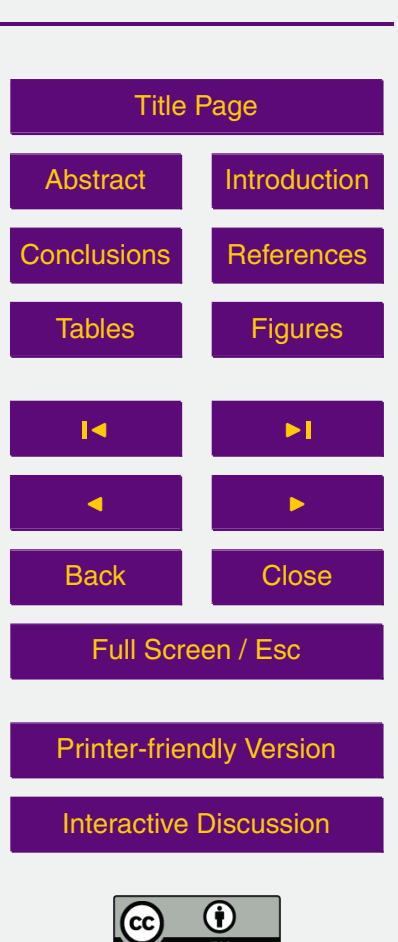
LGM temperature decrease of $5.1^{\circ} \mathrm{C}$ suggested for East African Lakes (Loomis et al., 2012). The lowering of temperatures during the LGM in East Africa decreased to 5$6^{\circ} \mathrm{C}$ on average, which also matches the reduction of the SST's in the western Indian Ocean between $0^{\circ} \mathrm{N}$ and $20^{\circ} \mathrm{S}$ and west of $50^{\circ} \mathrm{E}$ (Anhuf, 2000). Results from other 5 east African high mountains show that the overall lowering of the vegetation belts during the LGM amounted to $\pm 700 \mathrm{~m}$ in the dry high mountains, whereas in the humid high mountains it amounted to $\pm 1000 \mathrm{~m}$ (Coetzee, 1967; Hamilton, 1982; Perrott and Street-Perrott, 1982; Maitima, 1991; Olago et al., 2000).

Despite the assumed vegetation zone shifts during the pre-LGM the taxa composi10 tion within the prevailing vegetation remained rather stable as proposed by the ordination of the pollen taxa. The variations in MAT, Tmin and MAP had only a minor impact on the taxonomic structure of the montane plant communities during that time.

\subsection{Holocene climate reconstruction}

Precipitation and temperature fluctuate strongly throughout the Holocene. Mid and late 15 Holocene MAT is between 0.4 and $1.4{ }^{\circ} \mathrm{C}$ lower than today. MAP is between 4 and $20 \%$ lower than today and the Tmin exceed the frostline just after 6 ka for the first time in the record. This suggests increased unstable climate conditions throughout the Holocene, which is a common phenomenon in the tropics (Mayewski et al., 2004).

Our pollen-based reconstruction proposes very relatively warm and wet mid 20 Holocene around 6 kyrBP). Heavy convective precipitation for around $6 \mathrm{kyrBP}$ also is suggested by $\delta^{18} \mathrm{O}_{\text {diatom }}$ from Lake Challa (Barker et al., 2011).

The Kilimanjaro ice core records reflect this substantial cooling between 6.5 to 5.2 kyrBP (Thompson et al., 2002) which cannot be derived from our results. Neither does can we observe the dry conditions assumed from pollen record of Maundi Crater, 25 Kilimanjaro (Schüler et al., 2012) and hydrology reconstructions (BIT index) of Lake Challa at the foot of Mt. Kilimanjaro (Verschuren et al., 2009; Moernaut et al., 2010).

A second abrupt dry event picked up in our record around $2.5 \mathrm{kyrBP}$ is also recorded from the Kilimanjaro ice cores as enhanced dust input and lowered $\delta^{18} \mathrm{O}_{\text {ice }}$ (Thompson 214

\section{CPD}

10, 195-234, 2014

\section{Pollen-based temperature and precipitation inferences}

L. Schüler et al.

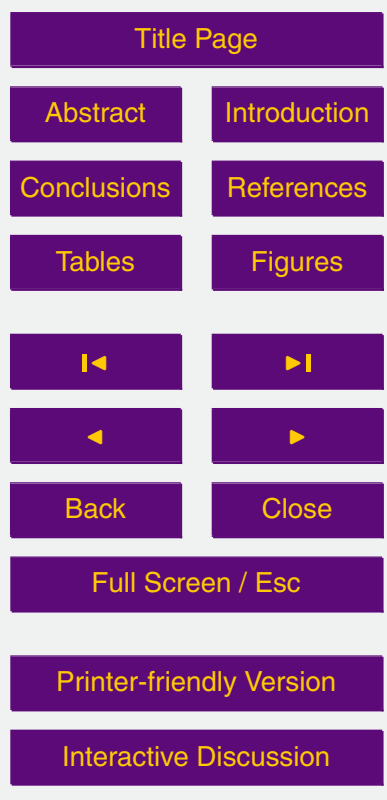

Interactive Discussion 
et al., 2002). While $\delta^{18} \mathrm{O}_{\text {diatom }}$ of Lake Challa also indicates greatest aridity around 2.5 $\mathrm{ka}$, the BIT index suggests increased surface runoff relative to the mid Holocene. Considering the slightly cooler late Holocene climate suggested by the Tanganyika TEX86 record (Tierney et al., 2008), our results support the suggestion by Barker (Barker 5 et al., 2011) that a weakened southeastern monsoon resulted in a reduced long rainy season and protracted main dry season during that period. Several other East African Lakes record major drought in the late Holocene: at Lake Victoria, the diatom-inferred lake level reached a minimum at 2.7-2.4 kyr (Stager and Mayewski, 1997) and Lake Naivasha, south Kenya, stood dry around $3 \mathrm{ka}$ (Richardson and Dussinger, 1986). After the remaining Holocene but does not experience any substantial long-term change. The mid Holocene to present cooling by $4{ }^{\circ} \mathrm{C}$ as suggested by temperature reconstruction from Sacred Lake, Kenya (Loomis et al., 2012) cannot be observed in our record.

Synchronously with the rise of annual temperature and increased precipitation in the Holocene, Tmin exceeds the frostline for longer periods. Since freezing stress is known to operate on long time scales and has a strong impact on plant communities (Körner, 2003; Holdridge, 1967) this microclimatic change to non-freezing minimum temperature caused profound change in the montane forest community at the WeruWeru site, which is indicated by the large increase in PC 1. The consistent vegetation change 20 continues for at least $1000 \mathrm{yr}$ after the first occurrence of phases without frost in the mid Holocene. This shows that despite more or less stable climate conditions, the only slightly higher Tmin triggered the reorganization of montane forest composition. This trigger effect would also explain the rather stable vegetation composition during the pre-LGM where minimum temperatures predominantly remain around below -0.6 to $25-1.0^{\circ} \mathrm{C}$.

It seems that despite repeated frost events throughout the Holocene, the generally more favourable, warmer and wetter climate conditions enabled the afro-montane forest to develop and expand on the slopes of Kilimanjaro. However, since our results also suggest, that the annual amount of precipitation is a crucial climate factor for the

\section{CPD}

10, 195-234, 2014

\section{Pollen-based temperature and precipitation inferences}

L. Schüler et al.

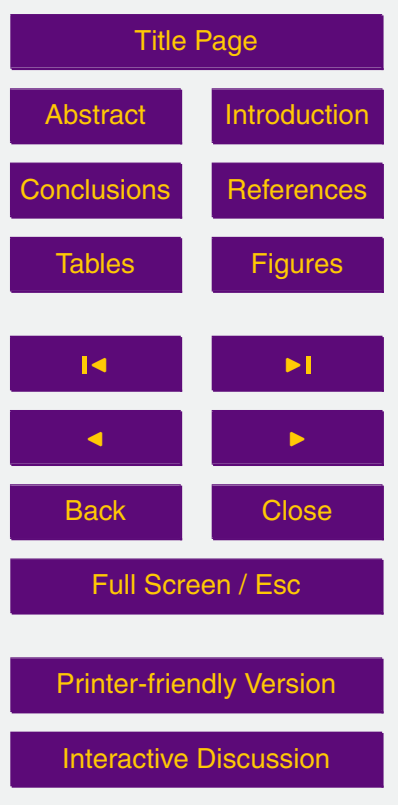

Interactive Discussion 
existence of montane forests, even a minor reduction in precipitation over the past decades as observed by Hemp (2005) could already have a major effect on the vegetation.

In prospective studies, the quantitative climate reconstruction can be improved by ad5 ditional modern pollen rain data, especially from lower elevations with submontane dry forests and colline savanna vegetation. It is unlikely that the temperature and precipitation patterns revealed by our record would be strongly modified since potential Late Glacial climate conditions are well covered by our modern pollen rain data set. However, warmer and especially drier phases would probably be refined since the climate 10 gradient covered here does not span elevations < 1900 ma.s.l. (with higher temperatures and decreasing precipitation). Further, outlier samples, such as samples with unusual pollen assemblages or unusual combination of environmental variables, or a pollen assemblage with poor relationship to MAP and/or MAT can strongly affect the predictive power of transfer functions (Birks et al., 1990; Hall and Smol, 1992) or eventually the respective reconstruction. Hutson (1976) points out that failure of transfer functions due to environmental conditions that have no modern analogue may be cryptic, but that chances for discovery are increased if more than one transfer function algorithm is applied to a given set of samples. Moreover, it needs to be explored in more detail, which taxa are to be included, and how they are weighted in the calibration, and eventually influence the reconstruction.

Hence, there is an urgent need of modern pollen-rain studies in tropical East Africa in order to establish pollen-climate relationships that show a strong and stable correlation. This will strongly improve the model performances and lead to much better predictions of climate parameter variations based on fossil pollen distribution.

\section{Conclusions}

Studies of the Quaternary period, especially the period from the LGM onwards, have two great advantages: a wealth of accurately dated information, and the fact that very

\section{CPD}

$10,195-234,2014$

\section{Pollen-based temperature and precipitation inferences}

L. Schüler et al.

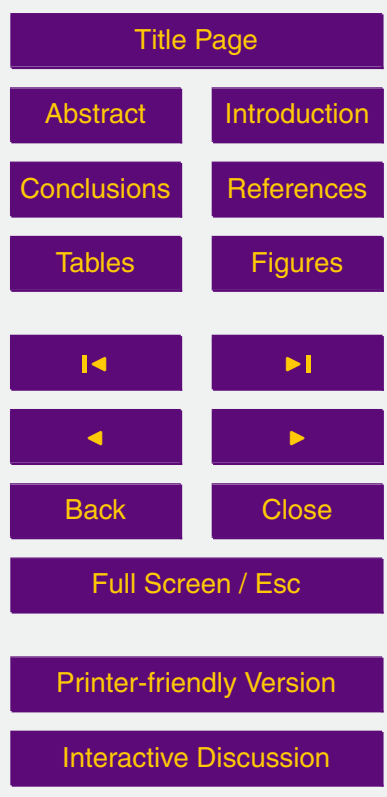

Interactive Discussion 
little macroevolution or natural extinction has taken place on this time scale so that observed biotic transitions can be interpreted based on knowledge of the present-day biota. It is possible to compute pollen transfer functions relating the distribution of fossil pollen to the distribution of the climatic parameter of interest. However, this implies 5 the existence of an adequate set of fossil samples and a representative training data set, hence, meaning good data on the distribution of environmental parameters under modern conditions. This relationship can then be used to estimate the climate values under past conditions. This computation is crucially dependent on a strong and stable correlation between climate parameter variations and fossil distribution. If these con10 straints are satisfied, the transfer functions derived through WA-PLS yield comparable results. The response of the pollen taxa to the climate variables differs between taxa. In our study, the majority of pollen taxa seems to follow a normal distribution along the gradient of climate variables. Directional trends in the taxa abundance along the elevation gradient recorded in this study are probably caused by the incomplete in15 ventory of the climate gradient. The assessment of the WA-PLS model performance shows that the type of data transformation used plays an important role for the reconstruction. Our best-fit transfer function is the one based on square root -transformed modern pollen-rain data, which is subset individually for each reconstructed climate variable by forward selection. We can show that it is important to include the information inherent in rare taxa. These taxa should receive special attention and need to be reinforced prior to model application. The reconstructed climate patterns for our fossil pollen record from the afro-montane forest on Mt. Kilimanjaro are consistent with the interpretation of pollen data in terms of vegetation history of montane forest and with general climate trends during the past $45 \mathrm{kyrBP}$ in tropical East Africa. The pre-LGM 25 is characterized by a climate about $1.7^{\circ} \mathrm{C}$ cooler and by about $25 \%$ drier than today. Towards the LGM, the annual minimum temperatures decreased and showed more fluctuations despite mostly unchanging mean annual temperature and only slightly increased annual precipitation. Due to a hiatus, the LGM is missing in the record. During the mid and late Holocene, our reconstructions reveal warmer and particularly more

\section{CPD}

$10,195-234,2014$

\section{Pollen-based temperature and precipitation inferences}

L. Schüler et al.

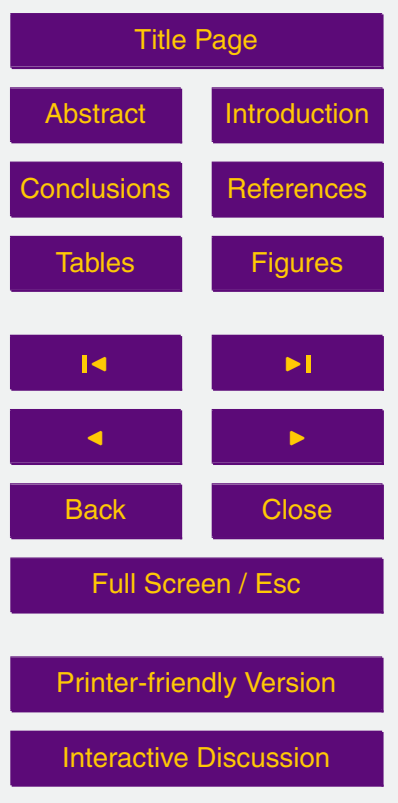


humid climate conditions. For the first time in this record, the annual minimum temperature exceeds $0^{\circ} \mathrm{C}$, which triggered profound changes in the vegetation and lead to the development and expansion of afro-montane forest on Mt. Kilimanjaro as it is found at 2600 ma.s.l. today.

5 Supplementary material related to this article is available online at http://www.clim-past-discuss.net/10/195/2014/cpd-10-195-2014-supplement. pdf.

Acknowledgements. We are grateful to the German Research Foundation (DFG) for financial support and the Tanzania Wildlife Research Institute (TAWIRI) for permitting field work in the

10 Klimanjaro National Park. Further L. Schüler would like to thank Thomas Gisecke for fruitful and inspiring discussions.

This Open Access Publication is funded by the University of Göttingen.

\section{References}

15 Anhuf, D., Ledru, M. P., Behling, H., Da Cruz, F. W., Cordeiro, R. C., van der Hammen, T., Karmann, I., Marengo, J. A., de Oliveira, P. E., Pessenda, L., Siffedine, A., Albuquerque, A. L., and Dias, P. L. D.: Paleo-environmental change in Amazonian and African rainforest during the LGM, Palaeogeogr. Palaeocl., 239, 510-527, 2006.

Assemien, P., Bonnefille, R., Cambon-Bou, G., Caratini, C., Cerceau, M., Dang, C. D., Fredoux, A., Guers, J., Guinet, P., Hideux, M., Hul-Thol, S., Keddam-Malplanche, M., Le Thomas, A., Lobreau-Callen, D., Lugardon, B., Maley, J., Mallea, M., Masure, E., Medus, J., Nigaud, M., Riollet, G., Senesse, S., Sivak, J., Soler, M., Stainier, F., Thanikaimoni, G., and Thiam, A.: Pollen et Spores d'Afrique tropicale, in: Traveaux et Documents de Géographie Tropical, edited by: Caratini, C. and Guinet, P., Centre d'Etude de Géographie Tropical, Association des Palynogues de Langue Française, Université de Bordeaux, Talence (France), 1974.

\section{CPD}

10, 195-234, 2014

\section{Pollen-based temperature and precipitation inferences}

L. Schüler et al.

\section{Title Page}

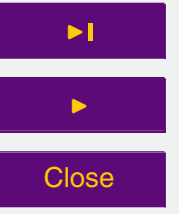

Back

\section{Full Screen / Esc}

Printer-friendly Version

Interactive Discussion 
Barker, P. A., Hurrell, E. R., Leng, M. J., Wolff, C., Cocquyt, C., Sloane, H. J., and Verschuren, D.: Seasonality in equatorial climate over the past $25 \mathrm{kyr}$ revealed by oxygen isotope records from Mount Kilimanjaro, Geology, 39, 1111-1114, 2011.

Bartlein, P. J., Webb III, T., and Fleri, E.: Holocene climatic change in the northern Midwest: 5 pollen-derived estimates, Quaternary Res., 22, 361-374, doi:10.1016/0033-5894(84)900292, 1984.

Bartlein, P. J., Prentice, I. C., and Webb, T.: Climatic response surfaces from pollen data for some eastern North American taxa, J. Biogeogr., 13, 35-37, 1986.

Bartlein, P. J., Harrison, S. P., Brewer, S., Connor, S., Davis, B. A. S., Gajewski, K., Guiot, J., Harrison-Prentice, T. I., Henderson, A., Peyron, O., Prentice, I. C., Scholze, M., Seppä, H., Shuman, B., Sugita, S., Thompson, R. S., Viau, A. E., Williams, J., and Wu, H.: Pollen-based continental climate reconstructions at 6 and 21 ka: a global synthesis, Clim. Dynam., 37, 775-802, doi:10.1007/s00382-010-0904-1, 2011.

Battarbee, R. W.: Diatom analysis and the acidification of lakes, Philos. T. R. Soc. B, 305, 15 451-477, 1984.

Birks, H. J. B.: Quaternary palaeoecology and vegetation science - current contributions and possible future developments, Rev. Palaeobot. Palyno., 79, 153-177, 1993.

Birks, H. J. B.: Quantitative paleoenvironmental reconstructions, in: Statistical Modelling of Quaternary Science Data, edited by: Maddy, D. and Brew, J. S., Quaternary Research Association, Cambridge, 161-254, 1995.

Birks, H. J. B.: Numerical tools in palaeolimnology - progress, potentialities, and problems, J. Paleolimnol., 20, 307-332, doi:10.1023/A:1008038808690, 1998.

Birks, H. J. B., Line, J. M., Juggins, S., Stevenson, S., and ter Braak, C. J. F.: Diatoms and pH reconstruction, Philos. T. R. Soc. B, 327, 263-278, 1990.

Birks, H. J. B., Heiri, O., Seppä, H., and Bjune, A. E.: Strength and weaknesses of quantitative climate reconstructions based on late quaternary biological proxies, The Open Ecology Journal, 3, 68-110, 2010.

Bonnefille, R. and Chalié, F.: Pollen-inferred precipitation time-series from equatorial mountains, Africa, the last $40 \mathrm{kyr}$ BP, Global Planet. Change, 26, 25-50, 2000.

30 Bonnefille, R., Chalié, F., and Guiot, J., and Vincens, A.: Quantitative estimates of full glacial temperature in equatorial Africa from palynological data, Clim. Dynam., 6, 251-257, 1992.
CPD

10, 195-234, 2014

\section{Pollen-based temperature and precipitation inferences}

L. Schüler et al.

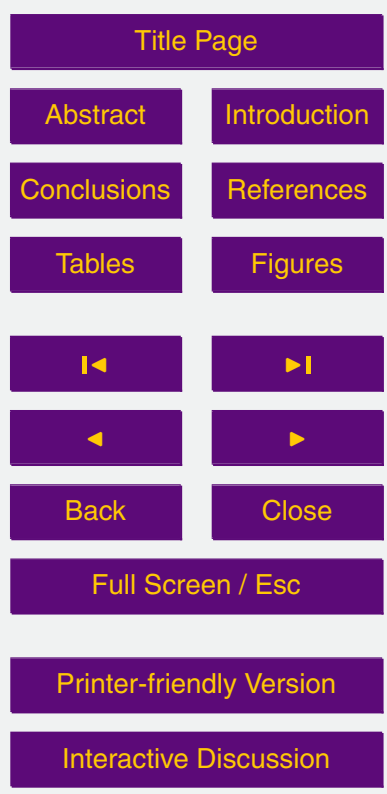


Cheddadi, R., Lamb, H. F., and Guiot, J., and van der Kaars, S.: Holocene climatic change in Morocco: a quantitative reconstruction from pollen data, Clim. Dynam., 14, 883-890, doi:10.1007/s003820050262, 1998.

Coetzee, J. A.: Pollen analytical studies in east and southern Africa, in: Palaeoecology of Africa 5 and of the Surrounding Islands and Antarctica, edited by: van Zindereren Bakker, E. M., Balkema, Cape Town, Amsterdam, 1-146, 1967.

Conolly, A. P.: 7. Some climatic and edaphic indications from the late-glacial flora, in: Proceedings of the Linnean Society of London, 172, 56-62, doi:10.1111/j.10958312.1961.tb00867.x, 1961.

10 Daniels, L. D. and Veblen, T. T.: Spatiotemporal influences of climate on altitudinal treeline in northern Patagonia, Ecology, 85, 1284-1296, 2004.

Faegri, K. and Iversen, J.: Textbook of Pollen Analysis, 4th edn., Wiley, Chichester, 1989.

Fritz, S. C., Juggins, S., Battarbee, R. W., and Engstrom, D. R.: Reconstruction of past changes in salinity and climate using a diatom-based transfer function, Nature, 352, 706-708, 1991.

15 Froyd, C. A. and Willis, K. J.: Emerging issues in biodiversity and conservation management: the need for a palaeoecological perspective, Quaternary Sci. Rev., 27, 1723-1732, doi:10.1016/j.quascirev.2008.06.006, 2008.

Guiot, J.: Methodology of the last climatic cycle reconstruction in France from pollen data, Methods for the Study of Stratigraphical Records, 80, 49-69, doi:10.1016/0031-0182(90)90033-4, 1990.

Guiot, J. and Vernal, A. de: Chapter 13 transfer functions: methods for quantitative paleoceanography based on microfossils, in: Developments in Marine Geology Proxies in Late Cenozoic Paleoceanography, edited by: Hillaire-Marcel, C. and De Vernal, A., Elsevier, Amsterdam, 523-563, 2007.

Guiot, J., Pons, A., de Beaulieu, J. L., and Reille, M.: A $140000 \mathrm{yr}$ continental climate reconstruction from two European pollen records, Nature, 338, 309-313, doi:10.1038/338309a0, 1989.

Hall, R. I. and Smol, J. P.: A weighted-avergaging regression and calibration model for inferring total phosphorus concentration fron diatoms in British Columbia, Freshwater Biol., 27, 417434, 1992.

Hamilton, A. C.: Environmental History of East Africa: A Study of the Late Quaternary, Academic Press, London, 1982.
CPD

10, 195-234, 2014

\section{Pollen-based \\ temperature and \\ precipitation \\ inferences}

L. Schüler et al.

Title Page

Abstract

Conclusions

References

Tables

Figures

14

4

Back

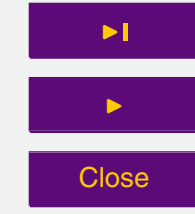

Full Screen / Esc

Printer-friendly Version

Interactive Discussion 
Harrison, S. P., Prentice, I. C., Barboni, D., Kohfeld, K. E., Ni, J., and Sutra, J.-P.: Ecophysiological and bioclimatic foundations for a global plant functional classification, J. Veg. Sci., 21, 300-317, doi:10.1111/j.1654-1103.2009.01144.x, 2010.

Hemp, A.: Ecology of the pteridophytes on the southern slopes of Mt. Kilimanjaro. Part II: Habitat selection, Plant Biol., 3, 493-523, 2001.

Hemp, A.: Climate change-driven forest fires marginalize the impact of ice cap wasting on Kilimanjaro, Glob. Change Biol., 11, 1013-1023, doi:10.1111/j.1365-2486.2005.00968.x, 2005.

Hemp, A.: Continuum or zonation? Altitudinal gradients in the forest vegetation of Mt. Kilimanjaro, Plant Ecol., 184, 27-42, 2006a.

10 Hemp, A.: Vegetation of Kilimanjaro: hidden endemics and missing bamboo, Afr. J. Ecol., 44, 305-328, doi:10.1111/j.1365-2028.2006.00679.x, 2006b.

Holdridge, L. R.: Life Zone Ecology, rev. edn., Tropical Science Center, San Jose, Costa Rica, 206 pp., 1967.

Huntley, B. and Prentice, I. C.: July temperatures in Europe from pollen data, $6000 \mathrm{yr}$ BP, Science, 241, 687-690, doi:10.1126/science.241.4866.687, 1988.

Huntley, B., Bartlein, P. J., and Prentice, I. C.: Climatic control of the distribution and abundance of beech in Europe and North America, J. Biogeogr., 16, 551-560, doi:10.2307/2845210, 1989.

Hutson, W. H.: Transfer Functions Under Non-Analogue Conditions, Brown University, Providence, RI, 1976.

Imbrie, J. and Kipp, N. G.: A new micro-palaeontological method for quantitative paleoclimatology: application to a late Pleistocene Caribbean cote, in: The Late Cenozoic Glacial Ages, edited by: Turekian, K., Yale University Press, New Haven, 71-181, 1971.

Jackson, S. T. and Williams, J. W.: Modern analogs in quaternary paleoecology: here today, gone yesterday, gone tomorrow? Annu. Rev. Earth PI. Sc., 32, 495-537, doi:10.1146/annurev.earth.32.101802.120435, 2004.

Jongman, R. H. G., ter Braak, C. J. F., and Van Tongeren, O. F. R.: Data Analysis in Community and Landscape Ecology, Cambridge University Press, New York, N.Y, xxi, 299, 1995.

Juggins, S.: Rioja: Analysis of Quaternary Science Data, R package version (0.8-4), available at: http://cran.r-project.org/package=rioja, 2012.

Körner, C.: Alpine Plant Life: Functional Plant Ecology of High Mountain Ecosystems, Springer Verlag, Berlin, Germany, 2003.

\section{CPD}

10, 195-234, 2014

\section{Pollen-based temperature and precipitation inferences}

L. Schüler et al.

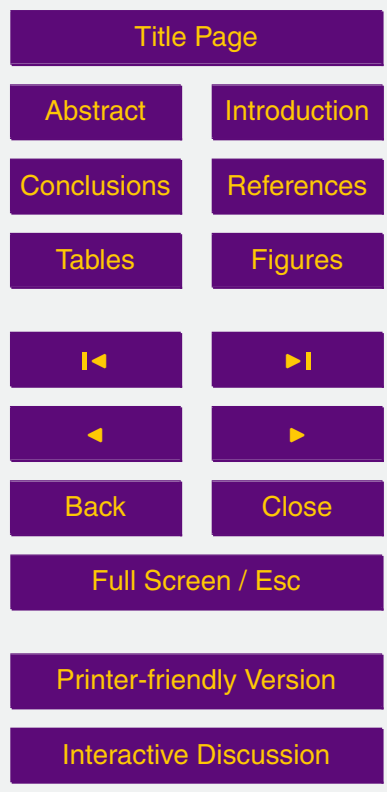


Larcher, W. and Bauer, H.: Ecological significance of resistance to low temperature, in: Physiological Plant Ecology I, edited by: Lange, O., Nobel, P., Osmond, C., and Ziegler, H., Encyclopaedia of Plant Physiology, Springer, Berlin Heidelberg, 403-437, 1981.

Lauer, W.: Klimatische Grundzüge der Höhenstufen tropischer Gebirge, Innsbruck: 40, 5 Deutscher Geographentag, 76-90, 1976.

Legendre, P. and Legendre, L.: Numerical Ecology, 3rd edn., Elsevier, Amsterdam, London, 2012.

Li, Y., Xu, Q., Liu, J., Yang, X., and Nakagawa, T.: A transfer-function model developed from an extensive surface-pollen data set in northern China and its potential for palaeoclimate reconstructions, Holocene, 17, 897-905, doi:10.1177/0959683607082404, 2007.

Loomis, S. E., Russell, J. M., Ladd, B., Street-Perrott, F. A., and Sinninghe Damsté, J. S.: Calibration and application of the branched GDGT temperature proxy on East African lake sediments, Earth Planet. Sc. Lett., 357, 277-288, doi:10.1016/j.epsl.2012.09.031, 2012.

Lotter, A., Birks, H. J., Hofmann, W., and Marchetto, A.: Modern diatom, cladocera, chironomid, and chrysophyte cyst assemblages as quantitative indicators for the reconstruction of past environmental conditions in the Alps, I. climate, J. Paleolimnol., 18, 395-420, doi:10.1023/A:1007982008956, 1997.

Macdonald, G. M., Bennett, K. D., Jackson, S. T., Parducci, L., Smith, F. A., Smol, J. P., and Willis, K. J.: Impacts of climate change on species, populations and communities: palaeobiogeographical insights and frontiers, Prog. Phys. Geog., 32, 139-172, doi: $10.1177 / 0309133308094081,2008$.

Maitima, M. J.: Vegetation response to climatic change in Central Rift Valley, Kenya, Quaternary Res., 35, 234-245, 1991.

Marchant, R., Cleef, A., Harrison, S. P., Hooghiemstra, H., Markgraf, V., van Boxel, J., Ager, T., Almeida, L., Anderson, R., Baied, C., Behling, H., Berrio, J. C., Burbridge, R., Björck, S., Byrne, R., Bush, M., Duivenvoorden, J., Flenley, J., De Oliveira, P., van Geel, B., Graf, K., Gosling, W. D., Harbele, S., van der Hammen, T., Hansen, B., Horn, S., Kuhry, P., Ledru, M.P., Mayle, F., Leyden, B., Lozano-García, S., Melief, A. M., Moreno, P., Moar, N. T., Prieto, A., van Reenen, G., Salgado-Labouriau, M., Schäbitz, F., Schreve-Brinkman, E. J., and Wille, M.: years ago, Clim. Past, 5, 725-767, doi:10.5194/cp-5-725-2009, 2009.

\section{CPD}

$10,195-234,2014$

\section{Pollen-based temperature and precipitation inferences}

L. Schüler et al.

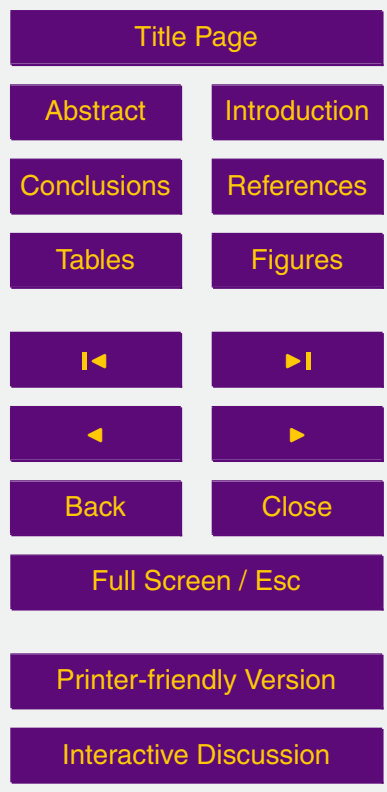


Markgraf, V., Webb, R. S., Anderson, K. H., and Anderson, L.: Modern pollen/climate calibration for southern South America, Palaeogeogr. Palaeocl., 181, 375-397, doi:10.1016/S00310182(01)00414-X, 2002.

Mayewski, P. A., Rohling, E. E., Curt Stager, J., Karlén, W., Maasch, K. A., David Meeker, L., 5 Meyerson, E. A., Gasse, F., van Kreveld, S., Holmgren, K., Lee-Thorp, J., Rosqvist, G., Rack, F., Staubwasser, M., Schneider, R. R., and Steig, E. J.: Holocene climate variability, Quaternary Res., 62, 243-255, doi:10.1016/j.yqres.2004.07.001, 2004.

Moernaut, J., Verschuren, D., Charlet, F., Kristen, I., Fagot, M., and de Batist, M.: The seismicstratigraphic record of lake-level fluctuations in Lake Challa: hydrological stability and change in equatorial East Africa over the last 140 kyr, Earth Planet Sc. Lett., 290, 214-223, 2010.

Müller, M. J.: Handbuch ausgewählter Klimastationen der Erde, Forschungsstelle Bodenerosion der Universität Trier, Trier, 1989.

Mumbi, C. T., Marchant, R., Hooghiemstra, H., and Wooller, M. J.: Late Quaternary vegetation reconstruction from the Eastern Arc Mountains, Tanzania, Quaternary Res., 69, 326-341,

Nakagawa, T., Tarasov, P. E., Nishida, K., Gotanda, K., and Yasuda, Y.: Quantitative pollenbased climate reconstruction in central Japan: application to surface and Late Quaternary spectra, Quaternary Sci. Rev., 21, 2099-2113, doi:10.1016/S0277-3791(02)00014-8, 2002.

Odum, E. P.: Fundamentals of Ecology, Saunders, Philadelphia, 1971.

20 Olago, D. O.: Vegetation changes over palaeo-time scales in Africa, Clim. Res., 17, 105-121, 2001.

Olago, D. O., Street-Perrott, F. A., Perrott, R. A., Ivanovich, M., and Harkness, D. D.: Late Quaternary glacial-interglacial cycle of climatic and environmental change on Mount Kenya, Kenya, J. Afr. Earth Sci., 29, 593-618, 1999.

Olago, D. O., Street-Perrott, F. A., Perrott, R. A., Ivanovich, M., Harkness, D., and Odada, E. O.: Long-term temporal characteristics of palaeomonsoon dynamics in equatorial Africa, Global Planet. Change, 26, 159-171, 2000.

Overpeck, J. T., Webb III, T., and Prentice, I. C.: Quantitative interpretation of fossil pollen spectra: dissimilarity coefficients and the method of modern analogs, Quaternary Res., 23, 30 87-108, doi:10.1016/0033-5894(85)90074-2, 1985.

Perrott, R. A. and Street-Perrott, F. A.: New evidence for a late Pleistocene wet phase in north intertropical Africa, Palaeoeco. A., 14, 57-75, 1982.

\section{CPD}

10, 195-234, 2014

\section{Pollen-based \\ temperature and \\ precipitation \\ inferences}

L. Schüler et al.

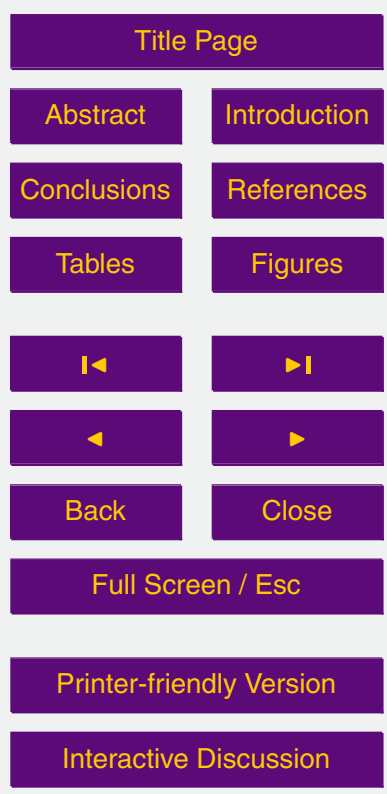


Pickett, E. J., Harrison, S. P., Hope, G., Harle, K., Dodson, J. R., Peter Kershaw, A., Colin Prentice, I., Backhouse, J., Colhoun, E. A., D’Costa, D., Flenley, J., Grindrod, J., Haberle, S., Hassell, C., Kenyon, C., Macphail, M., Martin, H., Martin, A. H., McKenzie, M., Newsome, J. C., Penny, D., Powell, J., Ian Raine, J., Southern, W., Stevenson, J., Sutra, J.-P., Thomas, I., van der Kaars, S., and Ward, J.: Pollen-based reconstructions of biome distributions for Australia, Southeast Asia and the Pacific (SEAPAC region) at 0,6000 and $18000{ }^{14} \mathrm{CyrBP}, \mathrm{J}$. Biogeogr., 31, 1381-1444, doi:10.1111/j.1365-2699.2004.01001.x, 2004.

Prentice, I. C., Bartlein, P. J., and Webb III, T.: Vegetation and climate change in eastern North America since the Last Glacial Maximum, Ecology, 72, 2038-2056, doi:10.2307/1941558, 1991.

Prentice, I. C., Jolly, D., and BIOME 6000 participants: Mid-Holocene and glacial-maximum vegetation geography of the northern continents and Africa, J. Biogeogr., 27, 507-519, doi:10.1046/j.1365-2699.2000.00425.x, 2000.

Richardson, J. L. and Dussinger, R. A.: Palaeolimnology of mid-elevation lakes in the Kenyan Rift Valley, Hydrobiologia, 143, 167-174, 1986.

Sachs, H. M., Webb III, T., and Clark, D. R.: Paleoecological transfer functions, Annu. Rev. Earth PI. Sc., 5, 159-178, 1977.

Sakai, A. and Larcher, W.: Frost survival of plants: Responses and adaptation to freezing stress, Ecological Studies, 62, Springer-Verlag, Berlin, New York, 321 pp., 1987.

20 Schüler, L.: Studies on Late Quaternary Environmental Dynamics (Vegetation, Biodiversity, Climate, Soils, Fire and Human Impact) on Mt. Kilimanjaro, Dissertation, GCBE - Göttingen Centre for Biodiversity and Ecology, University of Göttingen, Göttingen, 191 pp., 2013.

Schüler, L., Hemp, A., Zech, W., and Behling, H.: Vegetation, climate and fire-dynamics in East Africa inferred from the Maundi crater pollen record from Mt. Kilimanjaro during the last glacial-interglacial cycle, Quaternary Sci. Rev., 39, 1-13, 2012.

Seppä, H., Birks, H. J. B., Odland, A., Poska, A., and Veski, S.: A modern pollen-climate calibration set from northern Europe: developing and testing a tool for palaeoclimatological reconstructions, J. Biogeogr., 31, 251-267, doi:10.1111/j.1365-2699.2004.00923.x, 2004.

Sinninghe Damsté, J. S., Ossebaar, J., Schouten, S., and Verschuren, D.: Distribution of tetraether lipids in the $25 \mathrm{kyr}$ sedimentary record of Lake Challa: extracting reliable TEX86 and MBT/CBT palaeotemperatures from an equatorial African lake, Quaternary Sci. Rev., 50, 43-54, doi:10.1016/j.quascirev.2012.07.001, 2012.

\section{CPD}

10, 195-234, 2014

\section{Pollen-based \\ temperature and \\ precipitation \\ inferences}

L. Schüler et al.

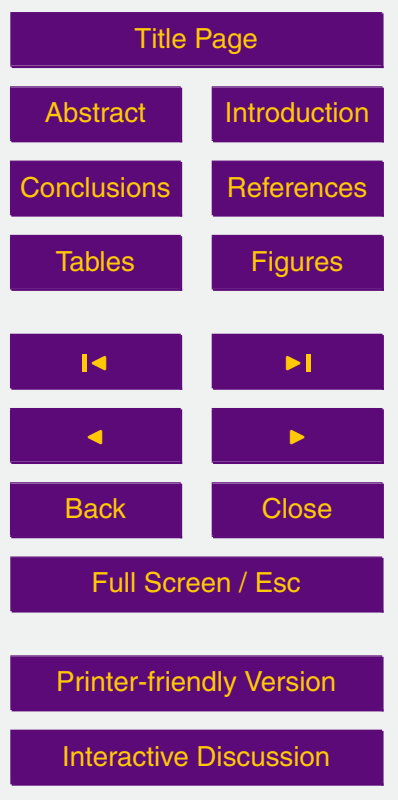


Spellerberg, I. F.: Monitoring Ecological Change, Cambridge University Press, Cambridge, England, 1991.

Stager, J. C. and Mayewski, P.: Abrupt early to mid-Holocene climatic transition registered at the Equator and the Poles, Science, 276, 1834-1836, doi:10.1126/science.276.5320.1834, 1997.

Taylor, D.: Late Quaternary pollen records from two Ugandan mires: evidence for environmental change in the Rukiga Highlands of southwest Uganda, Palaeogeogr. Palaeocl., 80, 283-300, 1990.

ter Braak, C. J. F. and Juggins, S.: Weighted averaging partial least square regression (WAPLS): an improved method for reconstructing environmental variables from species assemblages, Hydrobiologia, 269/270, 485-502, 1993.

ter Braak, C. J. F. and Šmilauer, P.: Canoco for Windows, Biometris - Plant Research International, Wageningen, the Netherlands, 1997.

ter Braak, C. J. F. and Šmilauer, P.: CANOCO Reference Manual and CanoDraw for Windows 15 User's Guide: Software for Canonical Community Ordination, Microcomputer Power, Ithaka, NY, USA, 2002.

Thompson, L. G., Mosley-Thompson, E., Davis, M. E., Henderson, K. A., Brecher, H. H., Zagorodnov, V. S., Mashiotta, T. A., Lin, P.-N., Mikhalneko, V. N., Hardy, D. R., and Beer, R.: Kilimanjaro Ice Core records: evidence of Holocene climate change in tropical Africa, Science, 298, 589-593, 2002.

Tierney, J. E., Russell, J. M., Huang, Y., Sinninghe Damsté, J. S., Hopmans, E. C., and Cohen, A. S.: Northern Hemisphere controls on tropical Southeast African climate during the past $60000 \mathrm{yr}$, Science, 322, 252-255, 2008.

Verschuren, D., Sinninghe Damsté, J. S., Moernaut, J., Kristen, I., Blaauw, M., Fagot, M., Haug, G. H., and CHALLACEA project members: Half-precessional dynamics of monsoon rainfall near the East African Equator, Nature, 462, 637-641, 2009.

Wake, D. B., Hadly, E. A., and Ackerly, D. D.: Biogeography, changing climates, and niche evolution: biogeography, changing climates, and niche evolution, P. Natl. Acad. Sci. USA, 106, 19631-19636, doi:10.1073/pnas.0911097106, 2009.

so Walker, I. R., Mott, R. J., and Smol, J. P.: Allerød-Younger Dryas lake temperatures from midge fossils in Atlantic Canada, Science, 253, 1010-1012, 1991.

Walter, H., Harnickell, E., and Mueller-Dombois, D.: Climate-diagram maps of the individual continents and the Ecological Climate Regions of the Earth, Springer, Berlin, 1975.

\section{CPD}

10, 195-234, 2014

\section{Pollen-based temperature and precipitation inferences}

L. Schüler et al.

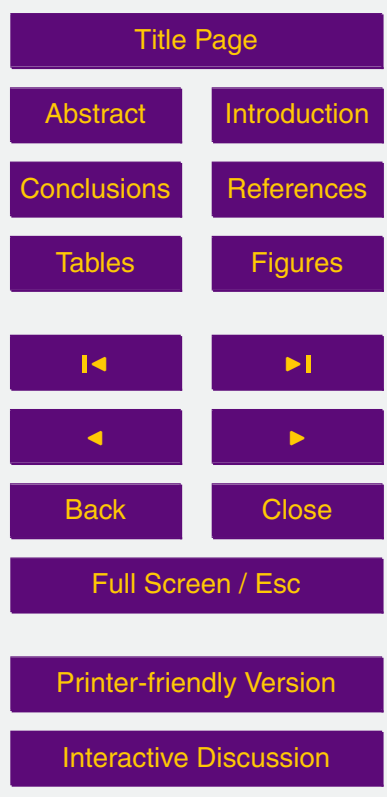

Interactive Discussion 
Webb III, T. and Bryson, R. A.: Late and postglacial climatic change in the northern Midwest, USA: quantitative estimates derived from fossil pollen spectra by multivariate statistical analysis, Quaternary Res., 2, 70-115, 1972.

Whittaker, R. H., Levin, S. A., and Root, R. B.: Niche, habitat, and ecotope, Am. Nat., 107, 321-338, 1973.

Willis, K. J., Bailey, R. M., Bhagwat, S. A., and Birks, H. J. B.: Biodiversity baselines, thresholds and resilience: testing predictions and assumptions using palaeoecological data, Trends Ecol. Evol., 25, 583-591, doi:10.1016/j.tree.2010.07.006, 2010a.

Willis, K. J., Bennett, K. D., Bhagwat, S. A., and Birks, H. J. B.: $4{ }^{\circ} \mathrm{C}$ and beyond: what did this mean for biodiversity in the past?, Syst. Biodivers., 8, 3-9, doi:10.1080/14772000903495833, 2010b.

Woodward, F. I. and Williams, B. G.: Climate and plant distribution at global and local scales, Vegetatio, 69, 189-197, doi:10.1007/BF00038700, 1987.

Xu, Q., Xiao, J., Li, Y., Tian, F., and Nakagawa, T.: Pollen-based quantitative reconstruction of 15 Holocene climate changes in the Daihai Lake Area, Inner Mongolia, China, J. Climate, 23, 2856-2868, doi:10.1175/2009JCLI3155.1, 2009.

Zagwijn, W. H.: Aspects of the Pliocene and Early Pleistocene vegetation in the Netherlands, Proefschrift-Leiden, 1960, "Ernest van Aelst", Maastricht, 3 pp., 1960.

Zagwijn, W. H.: Reconstruction of climate change during the Holocene in western and central Europe based on pollen records of indicator species, Veg. Hist. Archaebot., 3, 65-88, doi:10.1007/BF00189928, 1994.

Zech, M.: Evidence for Late Pleistocene climate change from buried soils on the southern slopes of Mt. Kilimanjaro, Tanzania, Palaeo, 242, 303-312, 2006.

\section{CPD}

10, 195-234, 2014

\section{Pollen-based temperature and precipitation inferences}

L. Schüler et al.

Title Page

Abstract Introduction

Conclusions References

Tables Figures

14

4

Back

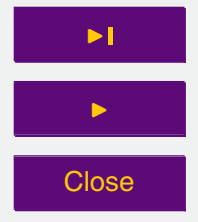

Full Screen / Esc

Printer-friendly Version

Interactive Discussion 


\section{CPD}

10, 195-234, 2014

\section{Pollen-based temperature and precipitation inferences} tation (MAP), mean annual temperature (MAT) and absolute minimum temperature (Tmin).

\begin{tabular}{|c|c|c|c|c|}
\hline Climate Variable & & 1st CCA axis & 2nd CCA axis & Permutation test result \\
\hline \multirow[t]{3}{*}{ MAP } & Eigenvalues & 0.2493 & 0.2374 & \multirow{3}{*}{$\begin{array}{l}\text { Pseudo-F: } 2.4 \\
P=0.002\end{array}$} \\
\hline & Species-environment correlation & 0.9361 & & \\
\hline & $\begin{array}{l}\text { Cumulative percentage variance } \\
\text { of species data }\end{array}$ & 16.59 & 32.38 & \\
\hline \multirow[t]{3}{*}{ MAT } & Eigenvalues & 0.2512 & 0.2545 & \multirow{3}{*}{$\begin{array}{l}\text { Pseudo-F: } 2.4 \\
P=0.002\end{array}$} \\
\hline & Species-environment correlation & 0.9604 & & \\
\hline & $\begin{array}{l}\text { Cumulative percentage variance } \\
\text { of species data }\end{array}$ & 16.71 & 33.65 & \\
\hline \multirow[t]{3}{*}{ Tmin } & Eigenvalues & 0.2576 & 0.2565 & \multirow{3}{*}{$\begin{array}{l}\text { Pseudo-F: } 2.5 \\
P=0.002\end{array}$} \\
\hline & Species-environment correlation & 0.9694 & & \\
\hline & $\begin{array}{l}\text { Cumulative percentage variance } \\
\text { of species data }\end{array}$ & 17.14 & 34.20 & \\
\hline
\end{tabular}

L. Schüler et al.

\section{Title Page}

\section{Abstract}

Introduction

Conclusions

References

Tables

Figures

14

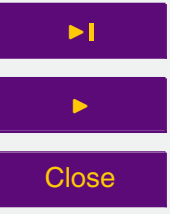

Back

Full Screen / Esc

Printer-friendly Version

Interactive Discussion 
Table 2. The pollen training subsets for the three climate variables derived from forward selection. Pollen taxa are given with their percentage contribution to the explanatory power of the complete subset. Pollen taxa with a contribution $\geq 20 \%$ were included in the transfer functions.

\begin{tabular}{llllll}
\hline \multicolumn{2}{c}{ MAP } & \multicolumn{2}{c}{ MAT } & \multicolumn{2}{c}{ Tmin } \\
Taxon & Contrib. (\%) & Taxon & Contrib. (\%) & Taxon & Contrib. (\%) \\
\hline Ericaceae & 63.8 & Ericaceae & 65.1 & Ocotea & 74 \\
Hagenia & 45.4 & Ocotea & 61.7 & Ericaceae & 63 \\
Hypericum & 43.9 & Macaranga & 59.6 & Macaranga & 59.1 \\
Mimosaceae & 41.1 & Artemisia & 53.8 & Thunbergia & 47.6 \\
Ocotea & 39.6 & Hypericum & 42.6 & Mimosaceaee & 45.7 \\
Artemisia & 34.5 & Mimosaceaee & 40.1 & Artemisia & 45.4 \\
Olea & 32.9 & Asteraceae & 38.3 & Olea & 43.8 \\
Thunbergia & 27.6 & Olea & 38.1 & Hypericum & 33.9 \\
Pauridiantha & 25.8 & Thunbergia & 36.3 & Hagenia & 30.6 \\
Chaetacme & 25.6 & Hagenia & 35.7 & Asteraceae & 30 \\
Piperaceae & 24.9 & Begonia & 33.7 & Begonia & 29.9 \\
Macaranga & 24.6 & Apocynaceae & 26.5 & Podocarpus & 28 \\
Trema & 24.5 & Combretum & 26.5 & Aneilema & 24.7 \\
Agarista & 24.1 & Ehretia & 26.5 & Mussaenda & 24.7 \\
Phyllantus & 24 & Strombosium & 26.5 & Piperaceae & 23.3 \\
Lythrum & 22.7 & Trichodesma & 26.5 & & \\
Pterolobium & 22.3 & Lythrum & 25.4 & & \\
Ilex & 22.2 & Prunus/Rubus & 23.9 & & \\
Polysphaeria & 20.9 & Celtis & 21.4 & & \\
Conyza & 20.6 & Cyphostemma & 21.1 & & \\
Nuxia & 20.6 & Plantago & 21.1 & & \\
Plumbago & 20 & Valeriana & 21.1 & & \\
Viola & 20 & Aneilema & 21 & & \\
Prunus/Rubus & 20 & Mussaenda & 21 & & \\
& & Podocarpus & 20 & & \\
\hline & & & & \\
\end{tabular}

CPD

10, 195-234, 2014

\section{Pollen-based temperature and precipitation inferences}

L. Schüler et al.

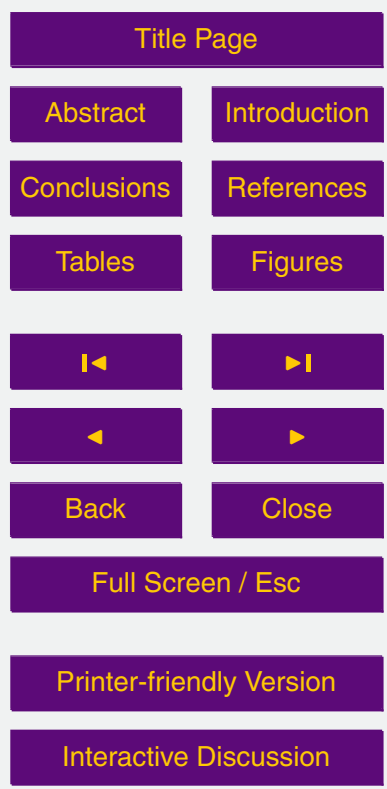

Interactive Discussion 


\section{CPD}

$10,195-234,2014$

\section{Pollen-based temperature and precipitation inferences}

Table 3. Values of Root Mean Square Error of Prediction (RSEMP), Squared correlation between bootstrap predicted and observed values $\left(R^{2}\right)$ and Randomisation $t$ test significance $(p)$ are given for the reconstructed climate variables MAP, MAT and Tmin. Values are given for the different number of components calculated for the WA-PLS model. ${ }^{* * *}(p<0.001)$ indicate the significant WA-PLS components as revealed by the randomized $t$ test. The RMSEP units are $\mathrm{mm}$ for MAP and ${ }^{\circ} \mathrm{C}$ for MAT and Tmin.

\begin{tabular}{llllllllll}
\hline & \multicolumn{3}{c}{ MAP } & \multicolumn{3}{c}{ MAT } & \multicolumn{3}{c}{ Tmin } \\
WAPLS comp. & RMSEP & $R^{2}$ & $p$ & RMSEP & $R^{2}$ & $p$ & RMSEP & $R^{2}$ & $p$ \\
\hline Comp 1 & 318.59 & 0.68 & $* * *$ & 1.15 & 0.79 & $* * *$ & 1.17 & 0.87 & $* \star *$ \\
Comp 2 & 367.83 & 0.59 & 0.72 & 1.14 & 0.79 & 0.41 & 1.15 & 0.88 & 0.14 \\
Comp 3 & 422.01 & 0.51 & 0.99 & 1.13 & 0.81 & 0.25 & 1.57 & 0.87 & 0.81 \\
\hline
\end{tabular}

L. Schüler et al.

Title Page

Abstract

Introduction

Conclusions

References

Tables

Figures

14

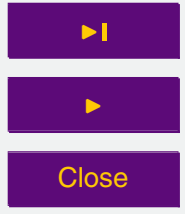

Back

Close

Full Screen / Esc

Printer-friendly Version

Interactive Discussion 


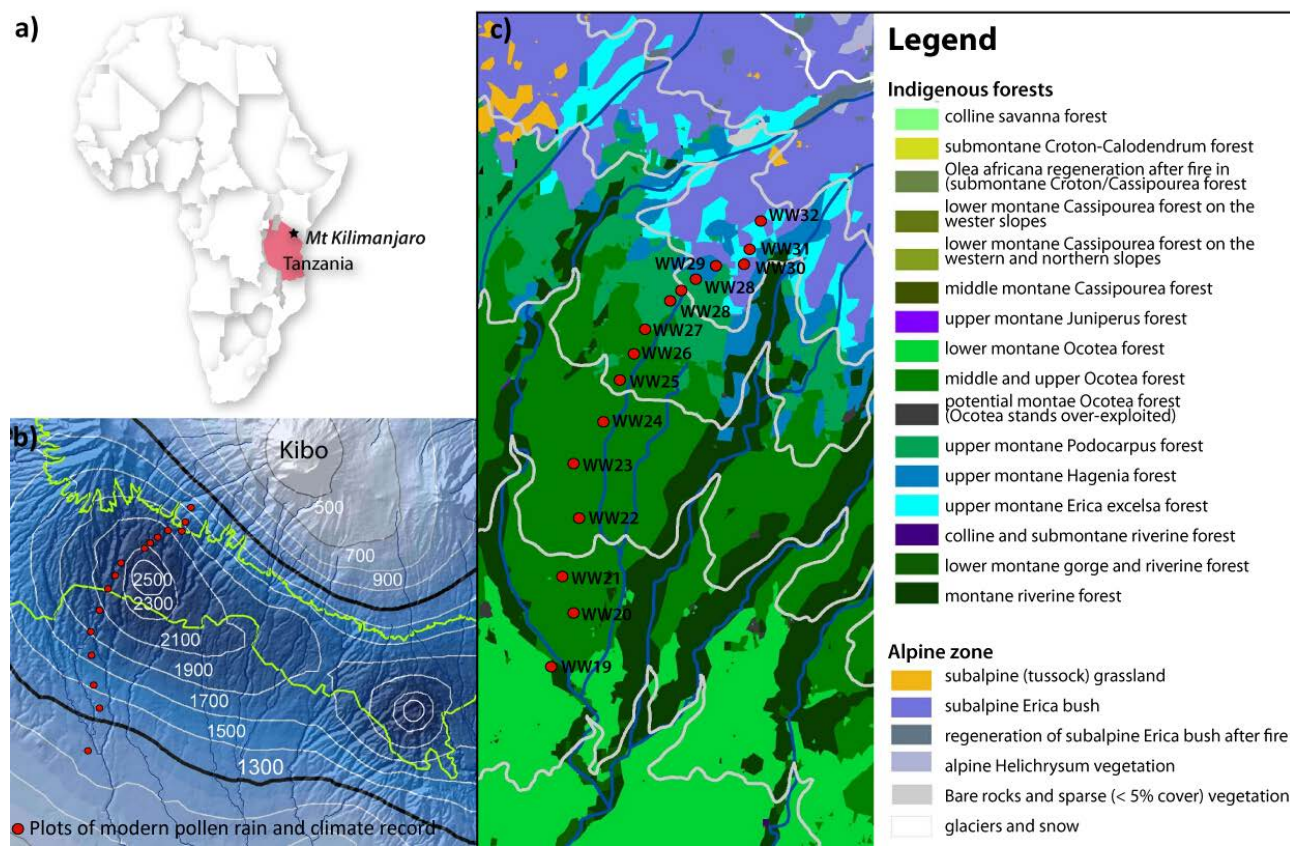

Fig. 1. (a) The study site Mt. Kilimanjaro in northern Tanzania. (b) Mean annual precipitation gradient on the southern slope of Mt. Kilimanjaro. Red circles indicate the WeruWeru transect sites, where the modern pollen-rain and the climate variables were recorded. (c) The vegetation types found on the southern slope of Mt. Kilimanjaro. Red circles indicate the WeruWeru transect sites.
CPD

10, 195-234, 2014

\section{Pollen-based temperature and precipitation inferences}

L. Schüler et al.

\section{Title Page}

4

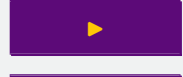

Back

Close

\section{Full Screen / Esc}

Printer-friendly Version

Interactive Discussion 


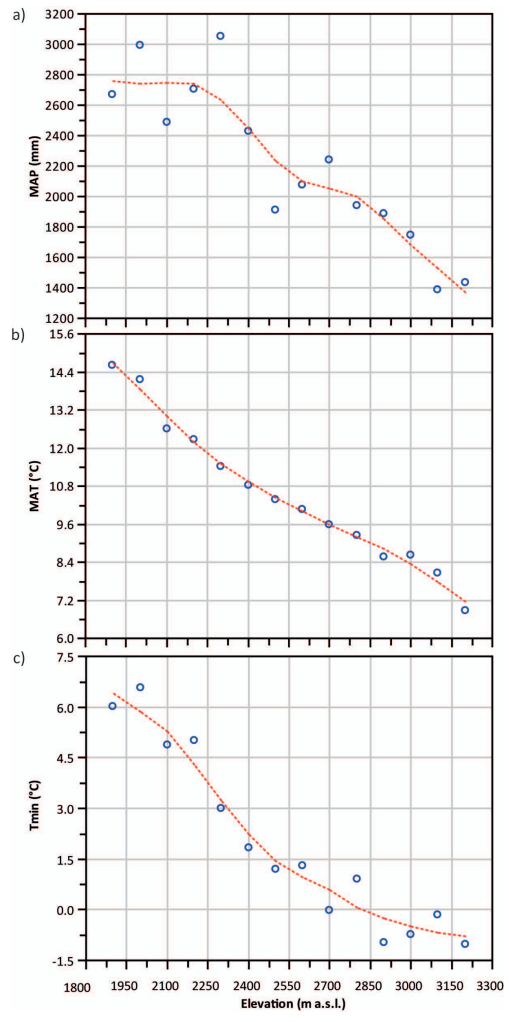

CPD

10, 195-234, 2014

\section{Pollen-based temperature and precipitation inferences}

L. Schüler et al.

Title Page

Fig. 2. Trend of mean annual precipitation (MAP), mean annual temperature (MAT) and absolute minimum temperature (Tmin) along the elevational gradient of the WeruWeru transect between 1900 and 3200 ma.s.I. on the southern slope of Mt Kilimanjaro. A local regression function (alpha: 0.45 ) was fitted to visualize the trend of the climate variables (a) MAP gradient (b) MAT gradient (c) Tmin gradient.
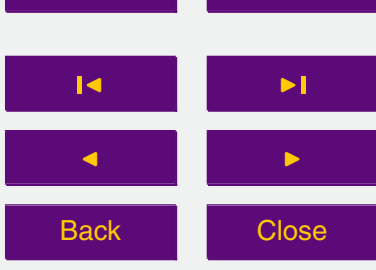

\section{Full Screen / Esc}

Printer-friendly Version

Interactive Discussion 




CPD

10, 195-234, 2014
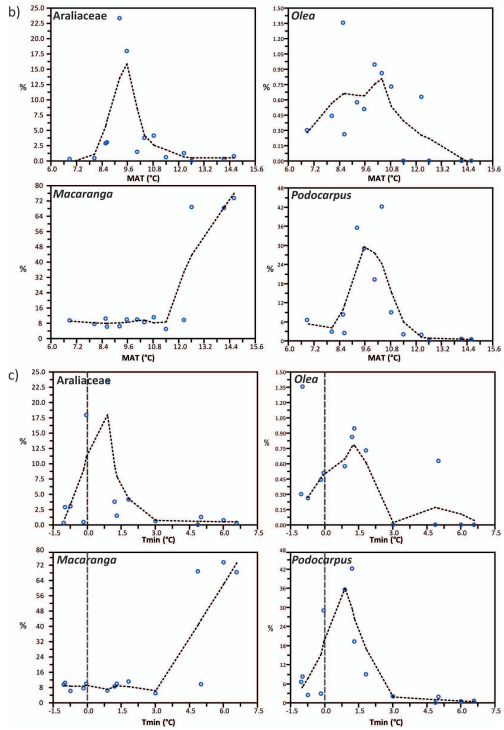

\section{Pollen-based temperature and precipitation inferences}

L. Schüler et al.

\section{Title Page}

Fig. 3. Response curves of the pollen taxa to the climate variables mean annual temperature (MAT), mean annual precipitation (MAP) and along the WeruWeru transect between 1900 and 3200 ma.s.l. The taxa percentage at each site/elevation was plotted again the climate parameters measured at these sites. A local regression function (alpha: 0.45) was fitted to visualize

the response trend (a) Taxa responses to MAP (b) Taxa responses to MAT.

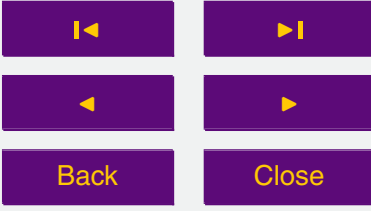

Full Screen / Esc

Printer-friendly Version

Interactive Discussion 


\section{CPD}

$10,195-234,2014$

\section{Pollen-based temperature and precipitation inferences}

L. Schüler et al.

\section{Title Page}

\section{Abstract}

Introduction

Conclusions

References

Fig. 4. Triplots of the Canonical Correspondence Analyses (CCA) of the modern pollen-rain data set from the WeruWeru transect, (a) CCA of the pollen taxa, the plots and the mean annual precipitation (MAP) as climate variable, (b) CCA of the pollen taxa, the plots and the mean annual temperature (MAT) as climate variable. The Eigenvalues are 0.2477 (CCA Axis 1) and 0.2465 (CCA Axis 2). The Eigenvalues are 0.2521 (CCA Axis 1) and 0.2270 (CCA Axis 2), (c) CCA of the pollen taxa, the plots and the absolute minimum temperature as climate variable. The Eigenvalues are 0.2508 (CCA Axis 1) and 0.2492 (CCA Axis 2).

\section{Tables}

\section{Figures}

14

4

Back

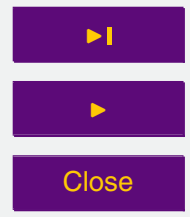

Full Screen / Esc

Printer-friendly Version

Interactive Discussion 


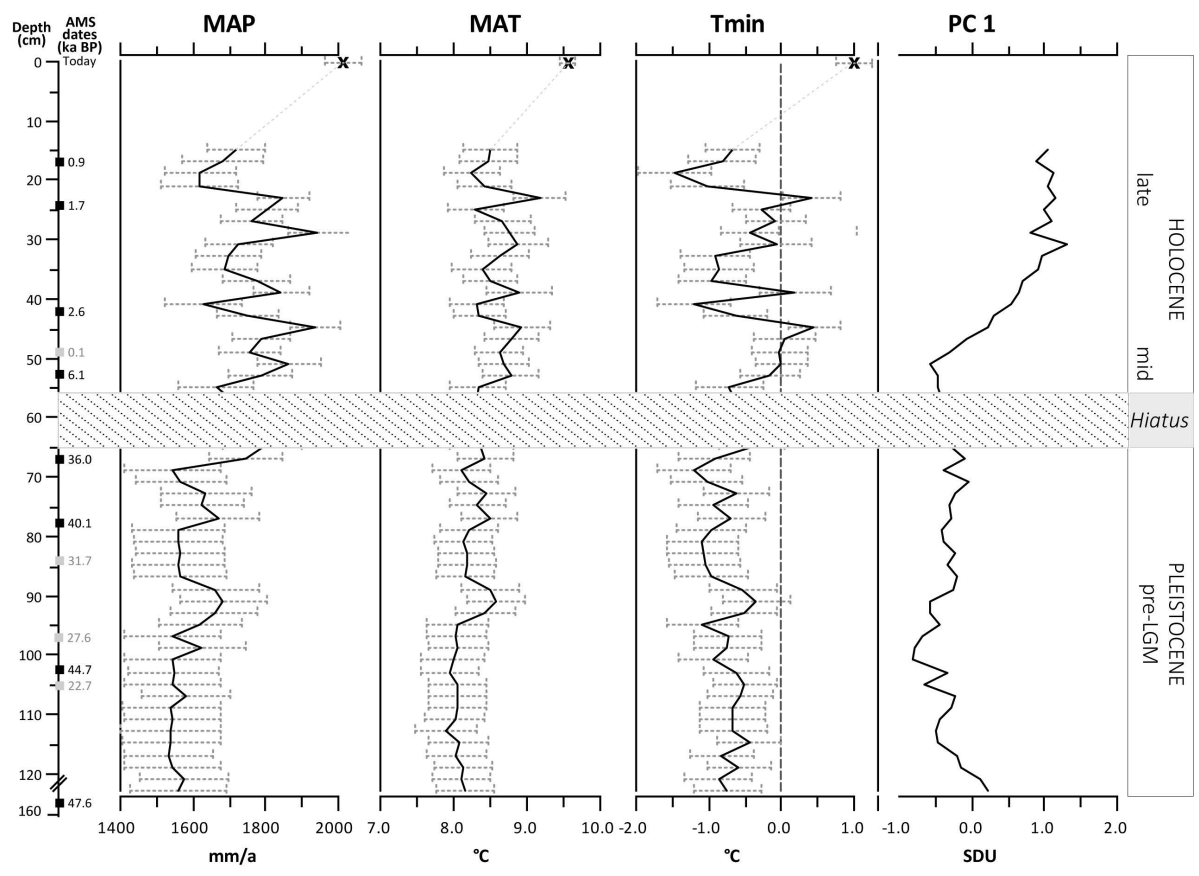

Fig. 5. Reconstruction of mean annual precipitation (MAP), mean annual temperature (MAT) and absolute minimum temperature (Tmin) of the WW26 pollen data set using weightedaveraging-least square regressions (WA-PLS). The error bars indicate the standard error of bootstrap estimated climate parameters of the correspondent WA-PLS component. For reference, the frost line is indicated in the Tmin graph (dashed grey line). AMS dates are given on the depth scale. The chronology suggests that the sediment above the hiatus (striated area) is part of the Holocene (ca 6-0 kyr) and sediment below the hiatus developed in the Late Glacial (47 to $36 \mathrm{kyrBP}$ ).
CPD

10, 195-234, 2014

\section{Pollen-based temperature and precipitation inferences}

L. Schüler et al.

Title Page

Abstract Introduction

Conclusions

References

Tables

Figures

14 $\Delta$

4

Back

Close

\section{Full Screen / Esc}

Printer-friendly Version

Interactive Discussion 